Review

\title{
Oxidation Catalysts for Elemental Mercury in Flue Gases-A Review
}

\author{
Beatrice-Andreea Dranga ${ }^{1,2, *}$, Liliana Lazar $^{1}$ and Heinz Koeser ${ }^{2, *}$
}

1 Department of Chemical Engineering, Faculty of Chemical Engineering and Environmental Protection, Gheorghe Asachi Technical University of Iasi, 73 Prof. D. Mangeron Street, Iasi 700050, Romania; E-Mail: lillazar@ch.tuiasi.ro

2 Environmental Protection Technology, Otto-von-Guericke University Magdeburg, c/o Engineering Sciences Centre, Martin-Luther University Halle-Wittenberg, Halle (Saale) D-06099, Germany

* Authors to whom correspondence should be addressed;

E-Mails: beatrice.dranga@iw.uni-halle.de (B.-A.D.); heinz.koeser@iw.uni-halle.de (H.K.); Tel.: +49-3461-46-2542/2857; Fax: +49-3461-46-2710.

Received: 29 December 2011; in revised form: 18 January 2012 / Accepted: 1 February 2012 / Published: 13 February 2012

\begin{abstract}
The removal of mercury from flue gases in scrubbers is greatly facilitated if the mercury is present as water-soluble oxidized species. Therefore, increased mercury oxidation upstream of scrubber devices will improve overall mercury removal. For this purpose heterogeneous catalysts have recently attracted a great deal of interest. Selective catalytic reduction (SCR), noble metal and transition metal oxide based catalysts have been investigated at both the laboratory and plant scale with this objective. A review article published in 2006 covers the progress in the elemental mercury $\left(\mathrm{Hg}^{\mathrm{el}}\right)$ catalytic oxidation area. This paper brings the review in this area up to date. To this end, 110 papers including several reports and patents are reviewed. For each type of catalyst the possible mechanisms as well as the effect of flue gas components on activity and stability are examined. Advantages and main problems are analyzed. The possible future directions of catalyst development in this environmental research area are outlined.
\end{abstract}

Keywords: mercury oxidation; catalysts; $\mathrm{Hg}^{\mathrm{el}}$ oxidation mechanisms; SCR; noble metal; transition metal oxide 


\section{Introduction}

Mercury emissions are of global concern due to their persistence, long-range mobility in the atmosphere, bio-accumulation in aquatic ecosystems and their neurotoxic impact on human health [1-3]. Therefore, the control and reduction of mercury emissions have become a major concern at national, regional and international level. For instance, within the United Nations Environmental Programme (UNEP), negotiations have started with a view to achieving an international mercury treaty to reduce the risks from global mercury emissions [1]. In December 2011, U.S. EPA issued the Mercury and Air Toxics Standards (MATS), with the aim of reducing emission levels of mercury and other toxic pollutants from power plants [4]. In Europe, the 2010/75/EU Industrial Emissions Directive [5] sets the average mercury emission limit value at $50 \mu \mathrm{g} / \mathrm{m}^{3}$ for waste incinerators. Concerns over the environmental effects of mercury emissions have triggered discussions on more stringent regulations in many countries. Consequently, mercury emissions abatement has become a new challenge for environmental engineering.

According to UNEP, estimates for 2005, flue gases from waste incinerators contribute $40 \mathrm{t}$ and cement plants $190 \mathrm{t}$. Coal fired power and industrial plants are the major source, with between $500 \mathrm{t}$ and $1920 \mathrm{t}$ of global anthropogenic mercury emissions to air [1]. During the combustion process all forms of mercury in fuel decompose into gaseous elemental mercury $\left(\mathrm{Hg}^{\mathrm{el}}\right)$ [6]. As the combustion gas cools down to $400{ }^{\circ} \mathrm{C}$, this elemental mercury is partially oxidized via gas phase reactions involving oxygen and halogen species [6]. $\mathrm{HgCl}_{2}$ and $\mathrm{HgO}$ are the volatile oxidized mercury $\left(\mathrm{Hg}^{\text {ox }}\right)$ species most likely to occur in flue gases. Oxidized mercury in flue gases is both reactive and water soluble, and therefore is easily captured by scrubbing processes. In wet flue gas desulfurization systems (WFGD) oxidized mercury is removed as a co-benefit. The effectiveness of the WFGD in the removal of oxidized mercury from flue gases depends on the operation conditions [7]. Generally, small concentrations of particle-bound mercury in flue gases are effectively removed in electrostatic precipitators or fabric filters.

Elemental mercury is fairly insoluble in water (nearly $50 \mu \mathrm{g} / \mathrm{L}$ ) and not effectively removed in scrubbers such as WFGD units. Therefore, processes that oxidize $\mathrm{Hg}^{\text {el }}$ in flue gases improve the effectiveness of mercury removal by wet scrubbers. In this context, one of the main challenges of mercury control strategies is the efficient conversion of elemental mercury into the oxidized form. Thermodynamic equilibrium calculation shows that for temperatures below $450{ }^{\circ} \mathrm{C}$, mercury in flue gases should exist mostly in the oxidized form. However, the cooling of flue gases in boilers under technical conditions is fast so that the mercury equilibrium at low temperatures is not reached. Here, the gas phase oxidation is kinetically limited. A selective heterogeneous catalyst, upstream of the scrubber, is needed to increase the speed of mercury oxidation reaction in the cooled flue gases [8].

The status of the $\mathrm{Hg}^{\text {el }}$ oxidation catalysts up to 2005 is covered in a review paper by Presto and Granite [9]. Since then this subject has gained increasing interest. Figure 1 presents a yearly frequency of the published literature over the past two decades. This figure is based on the compiled literature cited in the Presto and Granite paper [9] and the literature covered in this review. Starting in 2000, an increase in the number of papers covering the topic of catalytic oxidation of gaseous mercury is observed. To date, more than 200 papers are available on the topic. 
Figure 1. Yearly Frequency of Published Literature on Mercury Oxidation.

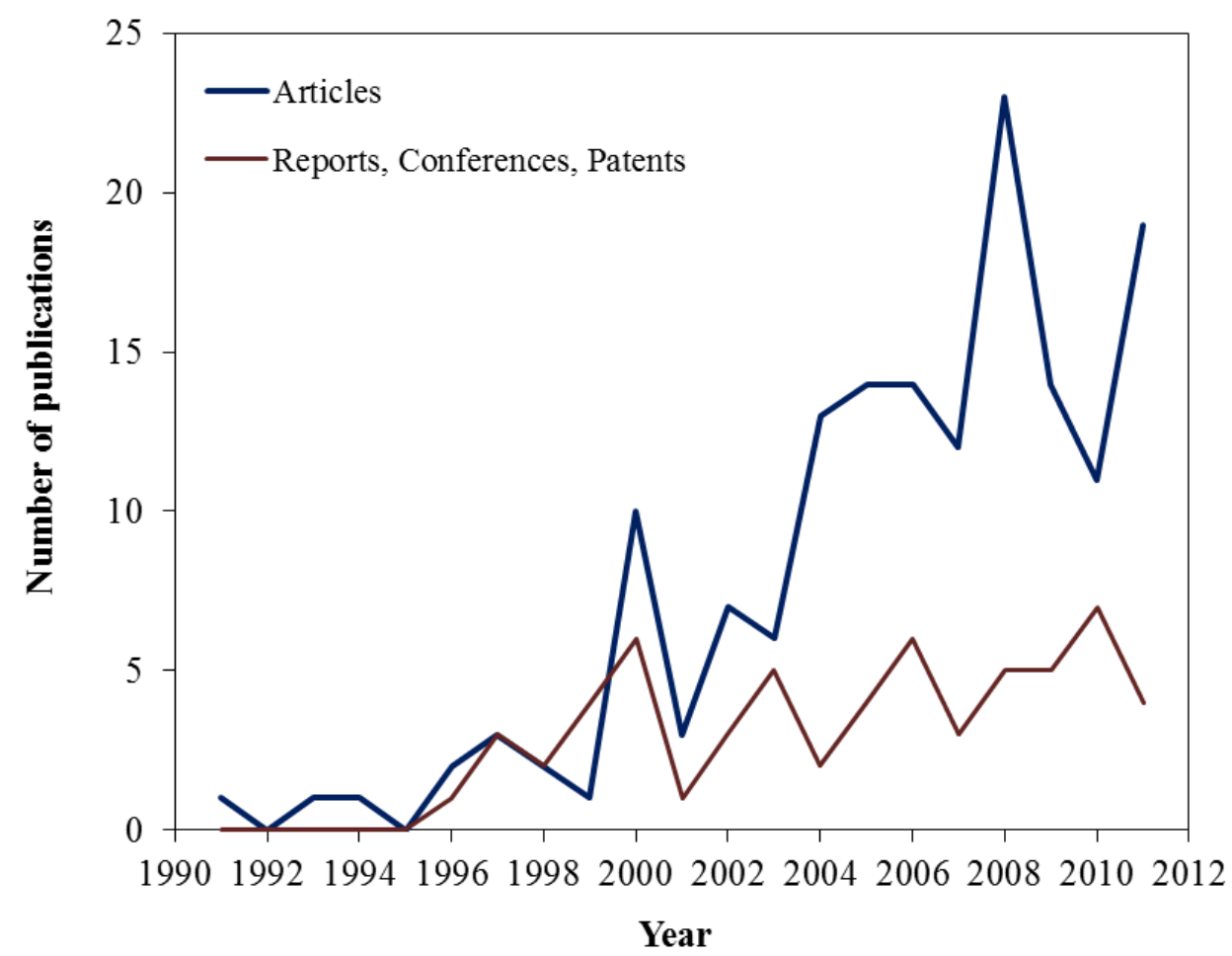

The present review article will discuss recent developments as well as some older papers which are excluded in the previous review paper, but whose importance is nowadays seen differently. For the sake of clarity this review will follow a similar structure as the previous review. Our understanding of the mechanism underlying the catalytic mercury oxidation process will be discussed first. Chapters concentrating on different mercury catalysts follow. Laboratory and plant scale investigations of noble metal and transition metal oxide based catalysts are discussed. Selective catalytic reduction (SCR)-DeNOx catalysts still attract the largest interest. The chapter on this group of catalysts is therefore very extensive.

Another aspect discussed in this review article involves the novel methods in the area of catalytic mercury oxidation. In recent years, a number of patent applications for mercury oxidation catalysts have appeared. A brief summary of their main features will be presented as well.

\section{Operation Condition and Constraints of Hg Oxidation Catalysts in Flue Gases}

All fuels, including renewables such as wood or gaseous, like natural gas, contain mercury. This mercury is almost completely volatized during the combustion process. Generally, the mercury content of different fuels varies between 0.01 and $2 \mu \mathrm{g} / \mathrm{g}$, resulting in flue gases with a mercury content of 1 to $200 \mu \mathrm{g} / \mathrm{m}^{3}$ [2]. The mercury content of natural gas is removed at the well, whereas the mercury from crude oil is removed at the refineries [10]. Therefore, the use of these fuels will not result in any appreciable mercury emissions. Consequently, the mobile combustion sources do not present a mercury emission issue. Mercury in coal is often associated with the pyrite fraction, and pyrite cleaning of coal does reduce $\mathrm{Hg}$ levels. However, fine grained pyrite $(<70 \mu \mathrm{m})$ is not removed by cleaning. Consequently, just one third of mercury in coal is removed by standard coal cleaning 
procedures [11]. Mercury from solid fuels is not completely removed by cleaning the fuel, and has to be captured from the flue gas.

The stable mercury species at combustion temperatures of around $1000{ }^{\circ} \mathrm{C}$ are exclusively in the elemental form. At temperatures below $450{ }^{\circ} \mathrm{C}$, equilibrium in flue gases is dominated by oxidized species such as the oxide and the halogenides $(\mathrm{X}=\mathrm{Cl}, \mathrm{Br}$ and $\mathrm{I})$. This low temperature equilibrium is generally not established in power plants and industrial incinerators. The halogen content of the fuel and of the flue gas determines the extent to which the $\mathrm{Hg}^{\mathrm{el}}$ is transformed into $\mathrm{Hg}^{\mathrm{ox}}$. The higher the halogen content the larger will be the fraction of oxidized species of the total mercury [12]. Below $500{ }^{\circ} \mathrm{C}$, the kinetics of the oxidation reaction of $\mathrm{Hg}^{\mathrm{el}}$ in flue gases are low in comparison to the flue gas residence times in incineration plants.

The halogen content of coal-like solid fuels is dominated by chlorine species. Chlorine appears in flue gases predominantly as $\mathrm{HCl}$. At low temperatures, $\mathrm{Cl}_{2}$ becomes the most stable species; however low kinetics do not allow for $\mathrm{Cl}_{2}$ formation in flue gases. The $\mathrm{HCl}$ content of flue gases from coal-combustion varies between 1 and $500 \mathrm{mg} / \mathrm{m}^{3}$. The bromine content in coal fuels is generally between 1 and $4 \%$ of the chlorine content [13]. Bromine species in the flue gas are more effective in oxidizing $\mathrm{Hg}^{\mathrm{el}}$. The iodine content of coal has not been often analyzed but is below the level of bromine.

Mercury oxidation catalysts do not decrease the mercury content of flue gases from industrial and power plant incinerators as such, but rather in combination with a scrubber or, less frequently, an absorber. For this purpose, the mercury oxidation catalyst has to be placed upstream of the flue gas scrubber. Wet scrubbing removes the acid components of flue gas, mainly $\mathrm{SO}_{2}, \mathrm{SO}_{3}, \mathrm{HCl}$ and $\mathrm{HBr}$, as well as the oxidized mercury.

The mercury catalyst may be placed before (high dust) and after (low dust) the dust removal device, which are often operated at temperatures around $280-400{ }^{\circ} \mathrm{C}$. Low dust placement is less prone to clogging by large dust particles. Here, all the volatile acid constituents of the flue gas are still present except for the nitrogen oxides $\mathrm{NO}_{\mathrm{x}}$. These are partially removed by ammonia-based SCR-or selective non-catalytic reduction (SNCR)-DeNOx technologies thereby introducing a slip concentration of $5 \mathrm{mg} / \mathrm{m}^{3}$ and higher of $\mathrm{NH}_{3}$.

In the high dust version, the most likely position to place the mercury catalyst is within the SCR-DeNOx reactor. This reactor is operated in $\mathrm{SO}_{2}$-containing flue gases at temperatures between 280 and $400{ }^{\circ} \mathrm{C}$. At this temperature range, the concentration of volatile arsenic (As) and selenium (Se) will still be high and needs special attention in the context of catalyst deactivation.

Another important constraint for mercury oxidation catalyst operation in a $\mathrm{SO}_{2}$-containing gas is its effect on the conversion reaction of $\mathrm{SO}_{2}$ to $\mathrm{SO}_{3} . \mathrm{SO}_{3}$ is poorly captured in most scrubbers. It forms sulfuric acid mist in flue gases that leave the plant. Another unwanted side reaction to be considered is the oxidation of $\mathrm{NO}$ to $\mathrm{NO}_{2}$. Although some $\mathrm{NO}_{2}$ is removed in scrubbers, as little as 10 to $15 \mathrm{ppm}$ of $\mathrm{NO}_{2}$ in the flue gas may cause a brownish plume from the chimney.

The oxygen content of flue gases resulting from combustion processes varies between 2 and 8 vol.-\%. This might also influence the performance of mercury oxidation catalysts.

It should be mentioned that because of the large volumes to be treated, mercury oxidation catalysts, like any other flue gas catalysts, has to be applied in a honeycomb or plate-like structure. This arrangement is preferred in order to reduce both pressure loss and energy requirements. 


\section{Proposed Mechanisms for the Catalytic Oxidation of Elemental Mercury}

Schematically, the oxidation of $\mathrm{Hg}^{\mathrm{el}}$ in the presence of a catalytic material can be described as follows:

$$
\mathrm{Hg}^{0}+\text { oxidizing species } \stackrel{\text { catalyst }, T^{\circ} \mathrm{C}}{\longrightarrow} \mathrm{Hg}^{2+}+\text { reduced species }
$$

The reaction rate of the gas phase oxidation of $\mathrm{Hg}^{\mathrm{el}}$ in flue gases is small at temperatures below $500{ }^{\circ} \mathrm{C}$. In order to achieve reasonable oxidation rate in this temperature region, the catalyst has to provide a very active oxidizing species or has to activate the mercury on its surface. For the adsorption process, the Lewis base and electron pair donor character of gaseous $\mathrm{Hg}^{\mathrm{el}}$ are important. Cation vacancies or Lewis acid sites on the surface of the catalytic active material can provide respectively active sites for the primary step or physical adsorption of elemental mercury. Other flue gas components compete with $\mathrm{Hg}^{\text {el }}$ for the active Lewis acid sites on the prospective catalytic material.

In recent years, papers on mercury oxidation catalyst increasingly discuss the underlying oxidation mechanisms. In the following sections, the mechanisms proposed to date are briefly discussed. It should be noted that, for almost all the mercury oxidation catalysts studied so far, the $\mathrm{HCl}$ and $\mathrm{HBr}$ constituents of flue gases to be treated are of vital importance. In the absence of these constituents, the oxidation rate is considerably reduced.

\subsection{Deacon Reaction}

Because of the importance of the halogen species, it is proposed that the $\mathrm{Hg}^{\mathrm{el}}$ oxidation in flue gases could be enhanced by chlorine atoms $\left(\mathrm{Cl}^{\circ}\right)$ or molecules $\left(\mathrm{Cl}_{2}\right)$ produced by the Deacon reaction [14]. Vosteen et al. [15,16] pointed out that the bromine species might be even more important, and that a high $\mathrm{Hg}^{\mathrm{el}}$ oxidation could be achieved in a tail-end SCR-DeNOx system even at low bromine concentrations by the bromine-Deacon reaction.

The Deacon reaction produces chlorine by catalytic oxidation of $\mathrm{HCl}$ with air or oxygen according to the overall reaction 2 . The reaction is reversible and exothermic.

$$
4 \mathrm{HCl}_{(\mathrm{g})}+\mathrm{O}_{2(\mathrm{~g})} \leftrightarrow 2 \mathrm{Cl}_{2(\mathrm{~g})}+2 \mathrm{H}_{2} \mathrm{O}_{(\mathrm{g})}\left(\Delta \mathrm{H}^{\circ}=-28.4 \mathrm{~kJ} / \mathrm{mol} \mathrm{HCl}\right)
$$

The reaction takes place at about 350 to $450{ }^{\circ} \mathrm{C}$ in the presence of copper, chromium, vanadium and $\mathrm{RuO}_{2}$ catalysts. This reaction is described by a Mars-van Krevelen type of reaction mechanism involving hydrogen abstraction from adsorbed $\mathrm{HCl}$, recombination and desorption of atomic chlorine, water desorption and oxygen adsorption [17]. $\mathrm{HBr}$ reacts in a similar manner, whereby the bromine-Deacon reaction produces more free bromine [18]. However, Griffin [19] suggested that $\mathrm{SO}_{2}$ depletes the Deacon $\mathrm{Cl}_{2}$ in the gas phase through the following gas phase reaction:

$$
\mathrm{Cl}_{2}+\mathrm{SO}_{2}+\mathrm{H}_{2} \mathrm{O} \leftrightarrow 2 \mathrm{HCl}+\mathrm{SO}_{3}
$$

In this way the positive effect of the Deacon-generated chlorine species might be inhibited. Bromine reacts to a smaller extent with $\mathrm{SO}_{2}$. 


\subsection{Eley-Rideal Mechanism}

This mechanism assumes that the elemental mercury present in the flue gas could react from the gas-phase (or as a weakly adsorbed) state with an adsorbed oxidant species, most likely $\mathrm{HCl}$. By invoking the Eley-Rideal mechanism, some authors [20] have tried to model the $\mathrm{Hg}^{\mathrm{el}}$ oxidation under SCR conditions. According to this mechanism, $\mathrm{HCl}$ is dissociatively adsorbed on the $\mathrm{V}_{2} \mathrm{O}_{5}$-active sites found on the SCR catalyst surface. $\mathrm{NH}_{3}$ and $\mathrm{HCl}$ species compete for the active sites. $\mathrm{Hg}^{\text {el }}$ reacts with the $\mathrm{V}_{2} \mathrm{O}_{5}$-chlorinated sites from the gas phase or as a weakly adsorbed species $[21,22]$ to form the final oxidation product, for example, according to the equations (4-6):

$$
\begin{gathered}
2 \mathrm{HCl}_{(\mathrm{g})}+2 \mathrm{~V}-\mathrm{O}-\mathrm{V}_{(\mathrm{s})} \leftrightarrow 2 \mathrm{~V}-\mathrm{OH}-\mathrm{V}-\mathrm{Cl}_{(\mathrm{s})} \\
2 \mathrm{~V}-\mathrm{OH}-\mathrm{V}-\mathrm{Cl}_{(\mathrm{s})}+\mathrm{Hg}_{(\mathrm{g})}^{0} \leftrightarrow 2 \mathrm{~V}-\mathrm{OH}-\mathrm{V}_{(\mathrm{s})}+\mathrm{HgCl}_{2(\mathrm{~g})} \\
2 \mathrm{~V}-\mathrm{OH}-\mathrm{V}_{(\mathrm{s})}+0.5 \mathrm{O}_{2(\mathrm{~g})} \leftrightarrow 2 \mathrm{~V}-\mathrm{O}-\mathrm{V}_{(\mathrm{s})}+\mathrm{H}_{2} \mathrm{O}_{(\mathrm{g})}
\end{gathered}
$$

In the light of most recent experimental findings, an Eley-Rideal mechanism with adsorbed $\mathrm{HCl}$ reacting with gas phase or weakly adsorbed $\mathrm{Hg}^{\mathrm{el}}$ does not seem plausible. Evidence of $\mathrm{HCl}$ adsorption on the catalyst surface was obtained by employing different surface analysis methods [23-25]. Following the reaction between $\mathrm{HCl}$ and the $\mathrm{V}_{2} \mathrm{O}_{5}$ active sites on the catalyst surface, several vanadyl oxychloride complexes such as $\mathrm{VOCl}_{2}, \mathrm{~V}_{2} \mathrm{O}_{3}(\mathrm{OH})_{2} \mathrm{Cl}_{2}, \mathrm{VO}_{2} \mathrm{Cl}_{2}$ are formed [23,24]. However, it has been shown by surface analysis means that $\mathrm{Hg}^{\mathrm{el}}$ adsorbs on various surfaces as well.

\subsection{Langmuir-Hinshelwood Mechanism}

Based on the Langmuir-Hinshelwood mechanism, the catalytic oxidation of $\mathrm{Hg}^{\mathrm{el}}$ takes place between elemental mercury and the oxidant species co-adsorbed on the catalyst surface. This oxidation mechanism is likely to occur in the presence of substrates which can adsorb both $\mathrm{HCl}$ and $\mathrm{Hg}^{\text {el }}$. A number of materials can adsorb $\mathrm{Hg}^{\text {el }}$ from the flue gas [26-30]. The adsorption of halogens is mentioned in the previous subchapter.

When investigating the catalytic oxidation of $\mathrm{Hg}^{\mathrm{el}}$ in the presence of $\mathrm{MnO}_{\mathrm{x}}-\mathrm{CeO}_{2} / \mathrm{TiO}_{2}$, $\mathrm{Li}$ et al. [26] proposed the Langmuir-Hinshelwood mechanism as a plausible reaction pathway. They explained the decrease of $\mathrm{Hg}^{\mathrm{el}}$ oxidation efficiency at temperatures above $250{ }^{\circ} \mathrm{C}$ with the decreasing adsorption of $\mathrm{Hg}^{\mathrm{el}}$ : therefore availability of one of the reaction partners. Eom et al. [25] formulated the rate limiting reaction of the adsorbed mercury and the absorbed chlorine species on a commercial SCR-DeNOx catalyst as:

$$
\text { SCR-cat }\left(\mathrm{V}^{4+}-\mathrm{O}\right) \mathrm{Hg}_{(\text {ads })(\mathrm{s})}^{+}+2 \mathrm{SCR}-\operatorname{cat}\left(\mathrm{V}^{4+}-\mathrm{Cl}\right) \leftrightarrow \mathrm{SCR}-\mathrm{cat}\left(\mathrm{V}^{4+}-\mathrm{O}\right){ }^{\cdots} \mathrm{HgCl}_{(\mathrm{ads})}{ }^{\cdots}\left(\mathrm{V}^{4+}\right)_{(\mathrm{s})}
$$

\subsection{Mars-Maessen Mechanism}

Initially, Granite et al. [28] proposed that the catalytic oxidation of $\mathrm{Hg}^{\mathrm{el}}$ could occur via a Mars-Maessen mechanism. More recent research widely uses the Mars-Maessen mechanism as a most likely pathway for $\mathrm{Hg}^{\mathrm{el}}$ oxidation in the presence of a metal oxide-based catalyst [31-34]. According to this mechanism, the $\mathrm{Hg}^{\mathrm{el}}$ oxidation takes place between the elemental mercury adsorbed on a metal 
oxide $\left(\mathrm{M}_{\mathrm{x}} \mathrm{O}_{\mathrm{y}}\right)$ surface and the lattice oxygen, forming a binary mercury oxide. The oxidation of $\mathrm{Hg}^{\mathrm{el}}$ could be described by the following equations for the $\mathrm{CoO} / \mathrm{TiO}_{2}$ system [33]:

$$
\begin{gathered}
\mathrm{Hg}_{(\mathrm{g})}+\text { catalyst surface } \rightarrow \mathrm{Hg}_{(\mathrm{ad})(\mathrm{s})} \\
\mathrm{Hg}_{(\mathrm{ad})(\mathrm{s})}+\mathrm{Co}_{\mathrm{x}} \mathrm{O}_{\mathrm{y}(\mathrm{s})} \rightarrow \mathrm{HgO}-\mathrm{Co}_{\mathrm{x}} \mathrm{O}_{\mathrm{y}-1(\mathrm{~s})} \\
\mathrm{HgO}-\mathrm{Co}_{\mathrm{x}} \mathrm{O}_{\mathrm{y}-1(\mathrm{~s})}+1 / 2 \mathrm{O}_{2(\mathrm{~g})} \rightarrow \mathrm{HgO}_{(\mathrm{ad})(\mathrm{s})}+\mathrm{Co}_{\mathrm{x}} \mathrm{O}_{\mathrm{y}(\mathrm{s})} \\
\mathrm{HgO}_{(\mathrm{ad})(\mathrm{s})}+2 \mathrm{HCl}_{(\mathrm{g})} \rightarrow \mathrm{HgCl}_{2(\mathrm{~g})}+\mathrm{H}_{2}
\end{gathered}
$$

Firstly, gaseous $\mathrm{Hg}^{\mathrm{el}}$ is physically adsorbed on the catalyst surface to form $\mathrm{Hg}^{\mathrm{el}}{ }_{(\mathrm{ad})}$. Then the $\mathrm{Hg}^{\mathrm{el}}{ }_{(\mathrm{ad})}$ reacts with the lattice oxygen from the catalyst to form a weakly adsorbed mercuric oxide. Some authors suggest that a part of the $\mathrm{Hg}^{\mathrm{el}}$ (ad) is directly oxidized by gaseous $\mathrm{O}_{2}$ to form $\mathrm{HgO}[14,34,35]$. The physical adsorption of $\mathrm{Hg}^{\mathrm{el}}$ on the catalyst surface takes place even at low reaction temperatures, although $\mathrm{Hg}_{(\mathrm{ad})}^{\mathrm{el}}$ conversion to $\mathrm{HgO}_{(\mathrm{ad})}$ is accelerated by increasing the temperature [14]. A further step of the Mars-Maessen mechanism involves the re-oxidation of catalytic metal oxide by gaseous oxygen. In the last step of this mechanism, the $\mathrm{HgO}_{(\mathrm{ad})}$ reacts with $\mathrm{HCl}$ or $\mathrm{HBr}$ to form the volatile mercury halogenides which are released from the catalyst surface.

The formation of mercury oxides and binary mercury oxides was supported by the surface analysis of spent catalysts $[33,35]$. Liu et al. [33] proposed that the $\mathrm{Hg}^{\mathrm{el}}$ oxidation product on $\mathrm{Co} / \mathrm{TiO}_{2}$ in the absence of $\mathrm{O}_{2}$ is an $\mathrm{Hg}_{2} \mathrm{O}-\mathrm{CoO}_{\mathrm{x}}$ oxide. According to their experimental observations this oxidation product reacts with gaseous $\mathrm{HCl}$, forming $\mathrm{Hg}^{\mathrm{el}}$ and volatile $\mathrm{HgCl}_{2}$ which are released from the catalyst surface.

\section{Noble Metal-Based Catalysts for $\mathrm{Hg}^{\text {el }}$ Oxidation}

Platinum group metals and gold are well-known oxidation catalysts in many different areas. For example, platinum group metals are widely used for the treatment of automobile exhaust emissions. Gold was considered to be less active in many oxidation applications in comparison with other noble metals. However, the topic of oxidation catalysis by gold is a fast growing field.

Noble metals catalysts are also promising for mercury oxidation applications due to their ability to adsorb $\mathrm{Hg}^{\mathrm{el}}$ on their surfaces and to form solid solutions in a process known as amalgamation. This property is well known for gold and has been exploited for decades in gold mining and analytical chemistry. The amalgamation type of adsorption can serve as a first step followed by oxidation and desorption of mercury as a volatile halide.

In the mercury-in-flue-gas oxidation field so far, gold has been the most widely applied noble metal, and will therefore be discussed in a separate chapter. The scarcity and high cost of noble metal-based catalysts limit their use. In Table 1 below, an overview of the investigations on mercury oxidation by noble metals catalysts is given. 
Table 1. Mercury oxidation over noble metal based catalysts.

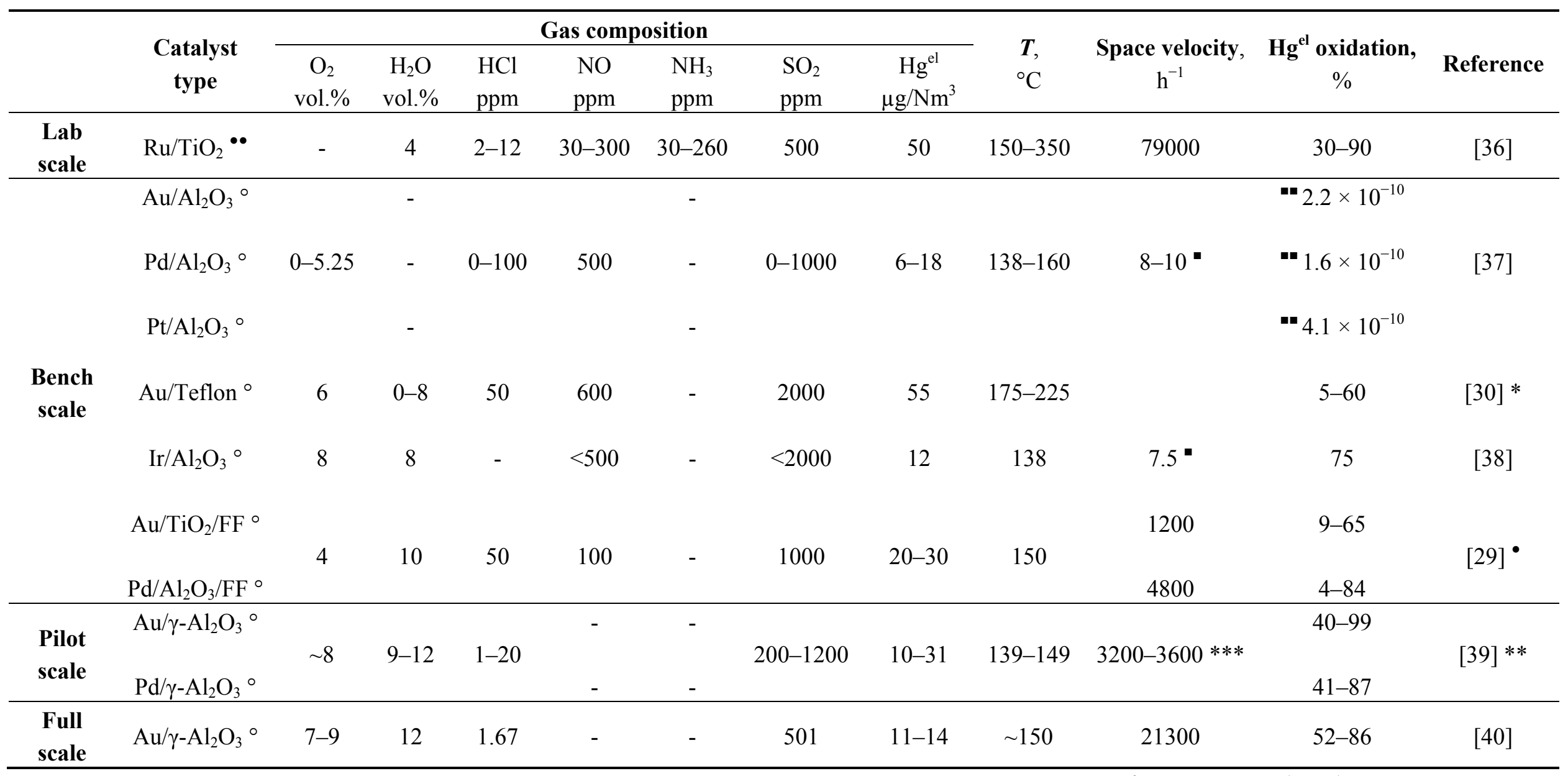

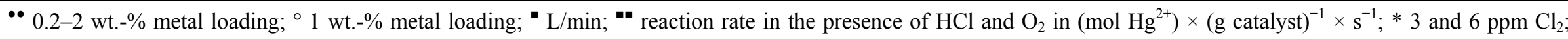

- $10 \mathrm{ppm} \mathrm{Cl}_{2}$; FF: fabric filters; *** gas flow rates $\left(\mathrm{m}^{3} / \mathrm{h}\right) ; * * 6-10 \mathrm{ppmv} \mathrm{HF}, 0-0.6 \mathrm{ppmv} \mathrm{Cl}_{2}, 0-0.04 \mathrm{ppmv} \mathrm{HBr}, 0.15 \mathrm{ppmv} \mathrm{HI}$. 


\subsection{Activity of Platinum Group Based Catalysts for the Oxidation of $\mathrm{Hg}^{\text {el }}$}

In the absence of halogen species and oxygen, noble metals adsorb elemental mercury even at temperatures as high as $400{ }^{\circ} \mathrm{C}$. This was confirmed in a recent lab scale study conducted by Poulston et al. [41] in fuel gasification gases containing $\mathrm{Hg}^{\mathrm{el}}$. Mercury adsorption capacity of platinum $\mathrm{Pt}$ and palladium $\mathrm{Pd}$ supported on $\mathrm{Al}_{2} \mathrm{O}_{3}$ were measured at temperatures between 204 and $388{ }^{\circ} \mathrm{C}$ in simulated fuel gases. Up to $14 \mathrm{wt} .-\% \mathrm{Hg}$ was detected in the Pd-based material $[41,42]$. In the presence of halogens the Pt group based catalysts oxidizes mercury.

Platinum Pt [8,37], palladium $\mathrm{Pd}$ [29,37], ruthenium oxide $\mathrm{RuO}_{2}$ [36], and iridium $\mathrm{Ir}$ [38] have been tested on laboratory and pilot scale in order to determine their potential as mercury oxidation catalysts.

The tests involved the use of noble metal catalysts as powders, foil and coated on different supports, such as: alumina beads [37], alumina beads imbedded in fabric filters [29] and titania [36]. The role of the supports is to ensure a high dispersion of the noble metals, maximizing the contact area between flue gas components and the catalytic active centers responsible for the mercury oxidation reaction. In some investigation a marked structure and size effect of the support were observed as well.

In the investigations reported on the mercury oxidation by Pt group metals, the presence of hydrogen halides was needed. The oxygen in flue gas seems to play also a certain part.

Presto and Granite [37] investigated the mercury oxidation at $149{ }^{\circ} \mathrm{C}$ under simulated flue gas conditions in the presence of $\mathrm{Pd}$ and $\mathrm{Pt}(1 \mathrm{wt} .-\%)$ supported on alumina beads. The $\mathrm{HCl}$ and $\mathrm{O}_{2}$ contents were varied. An interesting result was the gradual loss of catalytic activity for the $\mathrm{Pd}$ and $\mathrm{Pt}$ based catalysts over time. This deactivation behavior was explained by the formation of $\mathrm{Pt}$ and $\mathrm{Pd}$ oxides during exposure to $\mathrm{O}_{2}$ [37]. Surface bound chlorine seemed to be necessary for the oxidation of $\mathrm{Hg}^{\mathrm{el}}$. A marked decrease in mercury oxidation in gases with no $\mathrm{HCl}$ was observed. $\mathrm{HCl}$ higher than $50 \mathrm{ppm}$ caused no further increase on the oxidation rate. Schofield [8] explained the oxidation of $\mathrm{Hg}^{\text {el }}$ on $\mathrm{Pt}$ as a two-step process. In the first step the non-volatile $\mathrm{HgO}$ was formed. When $\mathrm{HCl}$ was present, the $\mathrm{HgO}$ was converted into the volatile $\mathrm{HgCl}_{2}$ and desorbed, thereby the reaction could proceed. The history of the catalysts investigated had a significant effect on their activity. It should also be noted that the mercury oxidation on $\mathrm{Pd}$ and $\mathrm{Pt}$ increased with temperature. Pt catalysts for diesel exhaust application are known to effectively oxidize $\mathrm{SO}_{2}$ to $\mathrm{SO}_{3}$ [43].

Results on this undesirable side effect reaction have not been reported so far for the $\mathrm{Hg}^{\mathrm{el}}$ oxidation catalysts. It is speculated that at the fairly low reaction temperature of $150{ }^{\circ} \mathrm{C}$ employed by Presto and Granite [37], this reaction might have not been fast enough. Pt based catalysts have also the potential to actively oxidize the NO in flue gases, as it is well known from the automobile exhaust field [44].

Hrdlicka et al. [29] found that at $150{ }^{\circ} \mathrm{C}$ and in the presence of $\mathrm{HCl} / \mathrm{Cl}_{2}$ and oxygen the mercury oxidation rate was within the range of $50-80 \%$ on 1 wt.- $\% \mathrm{Pd} / \mathrm{Al}_{2} \mathrm{O}_{3}$ coated fabric filters. $\mathrm{SO}_{2}$ and NO had an influence on the mercury oxidation activity.

The published research on $\mathrm{RuO}_{2} / \mathrm{TiO}_{2}$ catalysts pointed out that this system might be promising for mercury oxidation in coal-fired flue gases [36]. The lab scale investigation was conducted between 150 and $350{ }^{\circ} \mathrm{C}$ with most of the flue gas components present. No appreciable decrease of the mercury oxidation activity over 10 hours was reported. The poisoning effect of $\mathrm{SO}_{2}$ was small. The conversion of $\mathrm{SO}_{2}$ to $\mathrm{SO}_{3}$ by the catalyst was imperceptible. The authors observed that the oxidation activity increased with the $\mathrm{HCl}$ content up to $5 \mathrm{ppm}$ and leveled off thereafter. The catalyst was shown to 
generate some $\mathrm{Cl}_{2}$ from $\mathrm{HCl}$ according to the Deacon reaction. In the presence of $\mathrm{SO}_{2}$, no $\mathrm{Cl}_{2}$ could be detected in the gas phase, although $\mathrm{Hg}$ oxidation showed only a small decrease. The authors presumed that under these conditions the formation of atomic $\mathrm{Cl}$ species still took place and that the mercury reacted with these species [36]. Temperature increased the oxidation rate.

\subsection{Activity of Gold Based Catalysts for the Oxidation of $\mathrm{Hg}^{\text {el }}$}

Gold-based catalysts were found to be effective in a large number of catalytic reactions [45]. Recently, the potential use of gold-based catalysts in mercury pollution control applications has attracted much interest from academia as well as industry [29,30,37,40,46,47]. The studies have concentrated on the temperature range between 140 and $225{ }^{\circ} \mathrm{C}$ with, in most cases, 1 wt.- $\%$ gold on alumina and in one case with Au on a Teflon-coated quartz filter.

Due to the strong ability to adsorb $\mathrm{Hg}$ on its surface and to form an amalgam with it, gold is considered a very promising candidate for mercury oxidation. An interesting application of this $\mathrm{Au}-\mathrm{Hg}$ amalgamation property is the MerCAP process [48], which involves $\mathrm{Hg}^{\mathrm{el}}$ adsorption from flue gas on fixed $\mathrm{Au}$-coated structures followed by thermal regeneration of the gold sorbent and $\mathrm{Hg}$ recovery.

For the adsorbed mercury to be oxidized, a reactant is necessary. Chlorine atoms are identified as one likely species for this purpose. Gold readily adsorbs $\mathrm{Cl}_{2}$ molecules, thereby dissociating them into chlorine atoms $[29,30]$. The chlorine atoms react with mercury. The dissociative adsorption of $\mathrm{HCl}$ on $\mathrm{Au}$ is presumably weaker, since the dissociation energy of $\mathrm{Cl}_{2}$ is smaller and the bond length higher by comparison to $\mathrm{HCl}$ [49]. The importance of $\mathrm{HCl}$ adsorption is supported by the declining but continuing oxidation of $\mathrm{Hg}^{\mathrm{el}}$ when $\mathrm{HCl}$ from the gas stream is removed [37]. Presto and Granite [37] showed that increasing the $\mathrm{HCl}$ concentration above $50 \mathrm{ppm}$ had no further impact on the reaction rate with $\mathrm{Hg}^{\mathrm{el}}$. Zhao et al. [30] observed, for the elemental mercury oxidation across gold on Teflon-coated quartz filters, that in the presence of chlorine $\mathrm{Cl}_{2}(10 \mathrm{ppm})$ the oxidation of $\mathrm{Hg}^{\mathrm{el}}$ proceeded much faster than with $\mathrm{HCl}$. Apparently $\mathrm{HCl}$ decreased the effect of $\mathrm{Cl}_{2}$.

The addition of other flue gas constituents $\left(\mathrm{NO}, \mathrm{SO}_{2}, \mathrm{H}_{2} \mathrm{O}\right)$ did not seem to influence the elemental mercury oxidation in the presence of $\mathrm{Cl}_{2}$. Compared to the chlorine species, $\mathrm{NO}, \mathrm{SO}_{2}$ and $\mathrm{H}_{2} \mathrm{O}$ seemed to interact to a far lesser degree with $\mathrm{Au}$ surfaces [29,30]. The $\mathrm{Au} / \mathrm{TiO}_{2}$ coated fabric filters showed an increased mercury oxidation in the presence of $\mathrm{HCl}(50 \mathrm{ppm})$ and $\mathrm{NO}(100 \mathrm{ppm})$, suggesting that there might be a synergistic effect between $\mathrm{HCl}$ and $\mathrm{NO}$ in the presence of gold [29].

Removing the oxygen from an $\mathrm{HCl}$ containing simulated flue gas caused the $\mathrm{Hg}^{\text {el }}$ oxidation on $\mathrm{Au}$ catalyst to decrease [37]. Mercury oxidation on these catalysts increases with temperature [30,37].

Pilot $[39,46]$ and full scale $[40,47]$ investigations were conducted with the main objective to demonstrate the effectiveness and deactivation properties of a commercial gold catalyst wash coated on $\gamma$-alumina honeycomb substrate in promoting $\mathrm{Hg}^{\mathrm{el}}$ oxidation in flue gases from coal combustion. The catalyst modules were located downstream of a particulate control device [47] and in the flue gas scrubber inlet duct [40]. The flue gas contained only about $2 \mathrm{ppm} \mathrm{HCl}$ and $500 \mathrm{pm} \mathrm{SO}_{2}$. The investigation was conducted over a 17 months period.

Even after 6 months of operation in the demonstration plant, the percentage of oxidation of elemental mercury across the catalyst was only 3 percentage points below what was measured immediately after the catalyst was placed in service. However, after 13 months of operation a 
substantial loss of activity was measured. It is believed that some of this activity loss was real, but that a substantial portion was "artificial" in that it resulted from build-up of fly ash in the catalyst, which blocked the otherwise active surface area of the catalyst. Gas flow to parts of the second and third layers was blocked by fly ash buildup in the first layer [40]. An uneven distribution of the gas flow and the small channel width of $3.2 \mathrm{~mm}$ of the honeycomb catalyst contributed to the blocking. In summary it can be said that lab-scale, pilot-scale and full-scale mercury oxidation investigations show that gold-based catalysts are not subjected to fast deactivation under flue gas conditions $[37,40,46]$. One measurement campaign with respect to the $\mathrm{SO}_{2}$ conversion did not result in an appreciable increase of the $\mathrm{SO}_{3}$ content over the Au catalysts layer. It has to be mentioned that data are scarce on the influence of $\mathrm{Au}$ catalysts on the $\mathrm{SO}_{2}$ to $\mathrm{SO}_{3}$ conversion in flue gases. Boreskov et al. [50] measured a much lower $\mathrm{SO}_{2}$ oxidation rate for $\mathrm{Au}$ catalysts in comparison to Pt. Therefore the assumption is that this side reaction might be small. The effect of bromine species like $\mathrm{HBr}$ has also not been reported yet. Neither has the conversion of $\mathrm{NO}$ to $\mathrm{NO}_{2}$ over gold catalysts been studied.

\subsection{Summary}

Because of their undesirable side reactions, Pt based catalysts do not appear promising for mercury oxidation in flue gases. The recent laboratory results on $\mathrm{Ru} / \mathrm{TiO}_{2}$ catalysts for this application do not show appreciable $\mathrm{SO}_{2}$ oxidation but a high mercury oxidation rate, at temperatures around $300{ }^{\circ} \mathrm{C}$ and at $\mathrm{HCl}$ concentrations in the flue gas as low as $5 \mathrm{ppm}$. This avenue warrants further investigations.

Despite the plugging issues experienced, the recent demonstration plant results with gold-based catalyst in the low temperature range around $150{ }^{\circ} \mathrm{C}$ should encourage further efforts along this line. For this system, basic parameter studies on the effect of the different parameter importance in a flue gas environment and the gold distribution on the support are lacking.

\section{Mercury Oxidation by Transition Metal Oxide Catalysts}

The class of catalysts discussed in this chapter refers to the oxides of transition metals. A significant number of publications have discussed the activity of transition metal oxides-based catalysts for $\mathrm{Hg}^{\text {el }}$ oxidation in the $80-500{ }^{\circ} \mathrm{C}$ temperature range, see Table 2 . Their cost-effectiveness has made this group of catalysts attractive candidates for studies. The catalytic active oxides are deposited most commonly on alumina and titania. The role of the support is to not only stabilize and ensure a high metal dispersion degree but also in certain cases to participate in the $\mathrm{Hg}^{\mathrm{el}}$ oxidation reaction.

The activity for $\mathrm{Hg}^{\mathrm{el}}$ oxidation reaction of this catalysts group has so far been investigated mainly at laboratory scale under simulated flue gas conditions. For this purpose a number of parameters have been varied, such as:

- Loading and composition of the metal oxide material;

- Temperature and;

- $\mathrm{HCl}, \mathrm{Cl}_{2}, \mathrm{O}_{2}, \mathrm{H}_{2} \mathrm{O}$, $\mathrm{NO}$ and $\mathrm{SO}_{2}$ concentrations in the gaseous phase. 
Table 2. Mercury oxidation activity of different supported metals and metal oxides.

\begin{tabular}{|c|c|c|c|c|c|}
\hline \multirow[b]{2}{*}{ Catalysts } & \multicolumn{2}{|c|}{ Catalysts characteristics } & \multirow{2}{*}{$\begin{array}{c}\text { Reaction } \\
\text { temperature, } \\
{ }^{\circ} \mathrm{C} \\
\end{array}$} & \multirow{2}{*}{$\begin{array}{c}\text { Mercury } \\
\text { oxidation/removal, } \\
\%\end{array}$} & \multirow[b]{2}{*}{ Reference } \\
\hline & Synthesis method & $\begin{array}{c}\text { Metal loading, } \\
\text { wt.- } \%\end{array}$ & & & \\
\hline nano- $\mathrm{CuO}$ & commercial & 100 & $90-300$ & $20-96$ & {$[51]$} \\
\hline nano- $\mathrm{CuO}$ & commercial & 100 & 150 & 75 & {$[52]$} \\
\hline $\mathrm{CuCl}_{2} / \mathrm{TiO}_{2}$ & impregnation & $1.5-6$ & 350 & $60-100$ & {$[53]$} \\
\hline $\mathrm{CuCl}_{2} / \mathrm{TiO}_{2}-\mathrm{Al}_{2} \mathrm{O}_{3}$ & wetness impregnation & $0.25-9$ & $125-175$ & $28-62$ & {$[54]$} \\
\hline $\mathrm{CuCoO}_{4} / \gamma-\mathrm{Al}_{2} \mathrm{O}_{3}$ & thermal decomposition & $1 * * *$ & $100-450$ & $10-92$ & {$[55]$} \\
\hline Co-oxide $/ \mathrm{TiO}_{2}$ & sol-gel & $0.5-15$ & $90-360$ & $10->90$ & {$[33]$} \\
\hline nano- $\mathrm{Fe}_{2} \mathrm{O}_{3}$ & hydrothermal & 100 & $80-400$ & $<40$ & {$[34]$} \\
\hline $\mathrm{Fe}_{2} \mathrm{O}_{3} / \mathrm{TiO}_{2}$ & impregnation & $0.6-5$ & 80 & $60-80$ & {$[56]$} \\
\hline $\mathrm{MnO}_{\mathrm{x}} / \mathrm{Al}_{2} \mathrm{O}_{3}$ & wet impregnation & $1-8$ & $100-500$ & $45-90$ & {$[14]$} \\
\hline $\mathrm{Mn} / \alpha-\mathrm{Al}_{2} \mathrm{O}_{3}$ & wet impregnation & 1 & $100-250$ & $30-95$ & {$[57]$} \\
\hline $\mathrm{MnO}_{\mathrm{x}} / \mathrm{TiO}_{2}$ & wet impregnation & $10-20$ & $175-200$ & $\sim 90$ & {$[31]$} \\
\hline $\mathrm{MnO}_{\mathrm{x}}-\mathrm{CeO}_{2} / \mathrm{TiO}_{2}$ & impregnation & $0.18: 0.82: 1 * *$ & $120-400$ & $40->90$ & {$[26]$} \\
\hline $\mathrm{CeO}_{2} / \mathrm{TiO}_{2}$ & impregnation & $0.5-2 *$ & $120-400$ & $40-95$ & {$[58]$} \\
\hline $\mathrm{CeO}_{2} / \gamma-\mathrm{Al}_{2} \mathrm{O}_{3}$ & thermal decomposition & $3-15$ & $150-450$ & $33-90$ & {$[35]$} \\
\hline $\mathrm{V}_{2} \mathrm{O}_{5} / \mathrm{TiO}_{2}$ & sol-gel & $1-10$ & $100-500$ & $69-100$ & [59] \\
\hline $\mathrm{SiO}_{2}-\mathrm{TiO}_{2}$ & sol-gel & $12^{\bullet}$ & 135 & $10-90$ & {$[60]$} \\
\hline $\mathrm{SiO}_{2}-\mathrm{TiO}_{2}-\mathrm{V}_{2} \mathrm{O}_{5}$ & sol-gel & $6-18 \cdot ; 5 \cdot$ & $135-400$ & $40-100$ & [61] \\
\hline
\end{tabular}

* $\mathrm{CeO}_{2}: \mathrm{TiO}_{2}$ mass ratio; ** $\mathrm{MnO}_{2}: \mathrm{CeO}_{2}: \mathrm{TiO}_{2}$ mass ratio; *** $\mathrm{Co}: \mathrm{Cu}$ atomic ratio; $\stackrel{\bullet}{*}$ of $\mathrm{TiO}_{2} ;{ }^{\mathbf{*}} \mathrm{TiO}_{2} ;{ }^{\mathbf{M}} \mathrm{V}_{2} \mathrm{O}_{5}$.

Ghorishi et al. [62] investigated the influence of different fly ash components $\left(\mathrm{Al}_{2} \mathrm{O}_{3}, \mathrm{SiO}_{2}, \mathrm{Fe}_{2} \mathrm{O}_{3}\right.$, $\mathrm{CuO}$ and $\mathrm{CaO})$ on the extent of mercury oxidation. They observed that copper oxide $(\mathrm{CuO})$ and iron (III) oxide $\left(\mathrm{Fe}_{2} \mathrm{O}_{3}\right)$ present in the fly ash composition exhibited good catalytic activity towards the $\mathrm{Hg}^{\text {el }}$ oxidation reaction. These findings were followed up by Kamata, et al. [63] with an investigation on mercury oxidation by $\mathrm{HCl}$ over $\mathrm{TiO}_{2}$ supported metal oxide catalysts (with 1 wt.- $\% \mathrm{MO}_{\mathrm{x}} / \mathrm{TiO}_{2}$, with $\mathrm{M}=\mathrm{V}, \mathrm{Cr}, \mathrm{Mn}, \mathrm{Fe}, \mathrm{Ni}, \mathrm{Cu}$ and $\mathrm{Mo}$ ). $\mathrm{TiO}_{2}$ was essentially inactive. At $350{ }^{\circ} \mathrm{C}$ high $\mathrm{Hg}^{\mathrm{el}}$ oxidation was observed for $\mathrm{MoO}_{3}, \mathrm{~V}_{2} \mathrm{O}_{3}$ and $\mathrm{Cr}_{2} \mathrm{O}_{3}$ and the lowest for $\mathrm{NiO}$. In the presence of a $\mathrm{NH}_{3} / \mathrm{NO}$ molar ratio of 0.33 , the unreacted $\mathrm{NH}_{3}$ considerably depressed the $\mathrm{Hg}$ oxidation activity of all catalysts. A correlation was found between $\mathrm{NO}$ reduction and $\mathrm{Hg}$ oxidation activity.

\subsection{Copper/Cobalt Based Catalysts}

Copper oxide particles and the titania-supported- $\mathrm{CuO}$ are potential $\mathrm{Hg}^{\text {el }}$ oxidation catalysts in the presence of $\mathrm{HCl}$ [51,52]. Kamata et al. [52] compared the oxidation of gaseous $\mathrm{Hg}^{\text {el }}$ at $150{ }^{\circ} \mathrm{C}$ in the presence of $\mathrm{HCl}$ over different metal oxides. Among the catalysts tested, surface coated $\mathrm{CuO}$ nano-particles showed the highest activity. Conversion activity increased with $\mathrm{HCl}$ concentration. Formation of $\mathrm{Cu}_{2} \mathrm{Cl}(\mathrm{OH})_{2}$ was observed. Yamaguchi et al. [51] investigated further details of the $\mathrm{Hg}^{\text {el }}$ oxidation activity of $\mathrm{CuO}$ nano-particles under simulated flue gas conditions. The $\mathrm{CuO}$ nano-particles were dispersed on a quartz filter. An increase in $\mathrm{Hg}^{\mathrm{el}}$ oxidation (up to 96\%) was observed as the reaction temperature decreased from 300 to $90{ }^{\circ} \mathrm{C}$. A decrease in activity was observed when $\mathrm{CuO}$ nano-particle size increased from $50 \mathrm{~nm}$ to $620 \mathrm{~nm}$. Nano-particle size increased at temperatures above $150{ }^{\circ} \mathrm{C}$ because of sintering effects. 
The oxidation was $\mathrm{HCl}$ dependent and decreased considerably at concentrations of $5 \mathrm{mg} / \mathrm{m}^{3} \mathrm{HCl}$. When employing 1 wt.-\% CuO supported on heavy oil-fire fly ash (HOFA) a maximum of $98 \% \mathrm{Hg}$ oxidation was achieved in the presence of $20 \mathrm{ppm} \mathrm{HCl}$ and $350{ }^{\circ} \mathrm{C}$ [3].

At temperatures of $300{ }^{\circ} \mathrm{C}$, copper chloride $\left(\mathrm{CuCl}_{2}\right)$-impregnated titania exhibited high oxidation activity even in the absence of $\mathrm{HCl}$ [53]. The efficiency of $\mathrm{CuCl}_{2} / \mathrm{TiO}_{2}$ catalysts increased considerably when the $\mathrm{Cu}$ loading was higher than $3 \mathrm{wt} . \%$. In this case, it was assumed that oxidation of weakly bound $\mathrm{Hg}^{\mathrm{el}}$ might occur as a result of $\mathrm{Cl}$ radicals released following thermal decomposition of $\mathrm{CuCl}_{2}$ on the catalyst surface. The $\mathrm{CuCl}_{2}$ was restored by gas phase $\mathrm{HCl}$. A similar system, copper chloride $\left(\mathrm{CuCl}_{2}\right)$ on titania/alumina or alumina, was investigated by Miksche et al. [54]. The study focused on a low temperature regime of 125 to $175^{\circ} \mathrm{C}$. The $\mathrm{TiO}_{2}-\mathrm{Al}_{2} \mathrm{O}_{3}$ substrate provided a more active catalyst with respect to $\mathrm{Al}_{2} \mathrm{O}_{3}$. The $\mathrm{HCl}$ in the flue gas increased the $\mathrm{Hg}$ oxidation whereas $\mathrm{SO}_{2}$ had an adverse effect. In the studied temperature range with $2000 \mathrm{ppm} \mathrm{SO}_{2}$ and $40 \mathrm{ppm} \mathrm{HCl}$ in the flue gas, the $\mathrm{CuCl}_{2}$ catalyst provided considerably higher $\mathrm{Hg}$ oxidation rates than a conventional SCR-DeNOx catalyst with 1 wt.- $\% \mathrm{~V}_{2} \mathrm{O}_{5}$. However, no long-term stability data were provided.

Mei et al. [55] investigated the $\mathrm{Hg}^{\mathrm{el}}$ oxidation activity of $\mathrm{Al}_{2} \mathrm{O}_{3}$ loaded with 20 wt. $\% \mathrm{CuCoO}_{4}$ and $\mathrm{CuCoO}_{4}+\mathrm{NH}_{4} \mathrm{Cl}$ or $\mathrm{NH}_{4} \mathrm{Br}$. The catalyst was calcined at $400{ }^{\circ} \mathrm{C}$, by which point most of the ammonium salts evaporated; however a small amount of nitrogen doping in the $\mathrm{CuCoO}_{4}$ remained. At $350{ }^{\circ} \mathrm{C}$ and in $\mathrm{SO}_{2}$-containing simulated flue gas, mercury oxidations between 72 and $92 \%$ were achieved. The $\mathrm{NH}_{4} \mathrm{Cl}$ and $\mathrm{NH}_{4} \mathrm{Br}$ doped catalysts showed much higher $\mathrm{Hg}^{\text {el }}$ oxidation activity than $\mathrm{CuCoO}_{4} / \mathrm{Al}_{2} \mathrm{O}_{3}$, especially at temperatures between 100 and $350{ }^{\circ} \mathrm{C}$. The $\mathrm{SO}_{2}$ poisoning resistance of $\mathrm{CuCoO}_{4}$ was higher than those of the pure $\mathrm{Cu}$ and $\mathrm{Co}$ oxide. However, the $\mathrm{SO}_{2}$ tests were extended only over a $2 \mathrm{~h}$ period [64].

Cobalt oxide-based catalysts showed $\mathrm{Hg}^{\mathrm{el}}$ oxidation activity as well [33]. The activity of the $\mathrm{Co}-$ oxide $/ \mathrm{TiO}_{2}$ catalysts was affected by the Co loading and the oxidation temperature. $\mathrm{Hg}^{\mathrm{el}}$ oxidation efficiencies higher that $80 \%$ were achieved when the Co content was in the 2.5 and 7.5 wt.- $\%$ range and at temperatures between $120-330{ }^{\circ} \mathrm{C}$. Liu et al. [33] attributed the good catalytic performance of Co-based catalysts to well-dispersed $\mathrm{Co}_{3} \mathrm{O}_{4}$ species in the catalysts. In the absence of $\mathrm{HCl}$, mercury accumulated on the surface of the catalyst. A modified Mars-Maessen mechanism was considered; $\mathrm{Hg}^{\mathrm{el}}$ was adsorbed on the surface and then reacted with the lattice oxygen to form $\mathrm{Hg}-\mathrm{OCo}_{\mathrm{x}}$ bonds. The $\mathrm{HCl}$ then reacted with surface bound $\mathrm{HgO}$, releasing volatile $\mathrm{HgCl}_{2}$ and $\mathrm{H}_{2} \mathrm{O}$. It should be noted that between 240 and $360{ }^{\circ} \mathrm{C}$, NO was also oxidized by the catalyst to $\mathrm{NO}_{2}$. The influence of $\mathrm{SO}_{2}$ was not investigated. A thermal stability test over a $72 \mathrm{~h}$ period showed only a small decrease of activity.

\subsection{Iron/Manganese Based Catalysts}

Kong et al. [34] studied $\mathrm{Hg}^{\mathrm{el}}$ oxidation activity of rod-shaped nano- $\mathrm{Fe}_{2} \mathrm{O}_{3}$ in a fixed bed reactor arrangement. The $\mathrm{Hg}^{\text {el }}$ oxidation activity increased considerably with decreasing particle size. $\mathrm{Fe}_{2} \mathrm{O}_{3}$ powders with typical size of around $7 \mu \mathrm{m}$ showed no $\mathrm{Hg}$ oxidation activity where the nano-sized samples oxidized $30 \%$ of the $\mathrm{Hg}^{\mathrm{el}}$. $\mathrm{Hg}^{\mathrm{el}}$ oxidation increased significantly at temperatures between 75 and $300{ }^{\circ} \mathrm{C}$, and decreased at higher temperatures. The decrease of $\mathrm{Hg}^{\text {el }}$-oxidation activity at $400{ }^{\circ} \mathrm{C}$ was attributed to the sintering of the $\mathrm{Fe}_{2} \mathrm{O}_{3}$ nano-particles. Water vapor as well as oxygen in the flue gases influenced, to a certain extent, the $\mathrm{Hg}^{\mathrm{el}}$ oxidation by the $\mathrm{Fe}_{2} \mathrm{O}_{3}$ nano-particles. 
$\mathrm{Mn}-\mathrm{Fe}$ spinels [32,65] and nanosized cation-deficient $\mathrm{Fe}-\mathrm{Ti}$ spinels [66,67] were presented as effective materials for $\mathrm{Hg}^{\mathrm{el}}$ capture in the absence of $\mathrm{HCl}$. The $\mathrm{Hg}^{\mathrm{el}}$ sorption capacity of $\mathrm{Mn}-\mathrm{Fe}$ spinels was promoted by higher $\mathrm{Mn}$ contents. The sorption capacity was reduced in the presence of $\mathrm{SO}_{2}$. Sulfates were formed on the surface in this case. The formation of gas phase $\mathrm{SO}_{3}$ by these materials has not been assessed so far. $5 \mathrm{ppm} \mathrm{HCl}$ in the simulated gas phase reduced the adsorption and caused the release of oxidized mercury in effluent gas. Results on the $\mathrm{Hg}^{\mathrm{el}}$ oxidation in the presence of higher $\mathrm{HCl}$ concentrations in the gaseous phase are not available yet. It appears that the $\mathrm{Hg}^{\mathrm{el}}$, which is a Lewis base, is firstly physically adsorbed by Lewis acid sites on the Fe-Ti spinel and subsequently oxidized by $\mathrm{Fe}^{3+}$ cations present on the spinel surface [66]. When employing $\mathrm{Mn}-\mathrm{Fe}$ spinels, $\mathrm{Hg}^{\mathrm{el}}$ was captured and oxidized by $\mathrm{Mn}^{4+}$ cations from the surface [32,65]. The assumption, based on the available publication, is that the $\mathrm{Mn}-\mathrm{Fe}$ and $\mathrm{Fe}-\mathrm{Ti}$ spinels are more promising as $\mathrm{Hg}$ capture agents at temperatures around $150{ }^{\circ} \mathrm{C}$, and not as mercury oxidation catalysts in flue gases resulting from combustion processes.

In another investigation conducted at temperatures between 175 and $200{ }^{\circ} \mathrm{C}$, a 10 wt. $-\% \mathrm{MnO}_{2}$ on $\mathrm{TiO}_{2}$ strongly chemisorbed $\mathrm{Hg}^{\text {el }}$ in an $\mathrm{HCl}$ free gas [31]. $\mathrm{SO}_{2}$ (200 ppm) had a negative effect on $\mathrm{Hg}^{\text {el }}$ capture. Mercury was also captured in the absence of gas phase oxygen. This observation suggests a Mars-Maessen type of adsorption.

Several other studies suggested that manganese oxide-based catalysts may display good $\mathrm{Hg}^{\mathrm{el}}$ oxidation efficiency, at least under simulated flue gas conditions [14,57]. Qiao et al. [14] investigated the $\mathrm{MnO}_{\mathrm{x}} / \mathrm{Al}_{2} \mathrm{O}_{3}$ catalyst activity in the wide temperature range of 100 to $500{ }^{\circ} \mathrm{C}$. In the absence of $\mathrm{HCl}$ from the flue gas, the $\mathrm{MnO}_{\mathrm{x}}$ effectively adsorbed the gaseous $\mathrm{Hg}^{\mathrm{el}}$ with an optimum at $230{ }^{\circ} \mathrm{C}$. Adsorption was suppressed and high mercury oxidation efficiencies achieved in $\mathrm{HCl}$ or $\mathrm{Cl}_{2}$-containing flue gases. It appears that $\mathrm{Cl}_{2}(2 \mathrm{ppm})$ is as effective as $\mathrm{HCl}(20 \mathrm{ppm})$ in promoting the oxidation of $\mathrm{Hg}^{\mathrm{el}}$. $\mathrm{HCl}$ and $\mathrm{Cl}_{2}$ obviously desorb oxidized mercury, thereby regenerating the surface of the catalysts. The flue gas components $\mathrm{NO}, \mathrm{H}_{2} \mathrm{O}$ and $\mathrm{CO}_{2}$ had no significant impact on oxidation activity. $\mathrm{SO}_{2}$ exhibited a relatively low inhibitory effect, especially in the presence of $\mathrm{Cl}_{2}$. In a subsequent paper [57], mercury adsorption and oxidation in the presence of Mn oxide (1 wt.- $\% \mathrm{Mn}$ ), supported on $\alpha-\mathrm{Al}_{2} \mathrm{O}_{3}$, was studied within the $100-250{ }^{\circ} \mathrm{C}$ range. According to the XRD results, the Mn species on the support consisted of a mixture of $\mathrm{MnO}_{2}$ and $\mathrm{Mn}_{2} \mathrm{O}_{3}$. It appears that the catalyst was less active at temperatures below $250{ }^{\circ} \mathrm{C}$. Doping the $\mathrm{Mn}$-oxide $/ \alpha-\mathrm{Al}_{2} \mathrm{O}_{3}$ catalysts with molybdenum (Mo) resulted in high $\mathrm{Hg}^{\text {el }}$ oxidation in gases with $5 \mathrm{ppm} \mathrm{HCl}$, even in the presence of $\mathrm{SO}_{2}$. Most likely the Mo doping improved $\mathrm{MnO}_{\mathrm{x}}$ particle dispersion, thereby increasing the $\mathrm{Hg}^{\text {el }}$ oxidative potential at low temperatures [57]. The presence of Mo-Mn complexes was also supposed to increase the $\mathrm{SO}_{2}$ tolerance. It is speculated that the Deacon reaction, with its reactive chlorine generating capabilities, might be important for the overall reaction. The mercury oxidation rate was pseudo first order in the mercury concentration and dependent to the power 0.36 with respect to the $\mathrm{HCl}$ concentration in the flue gas.

\subsection{Cerium Based Catalysts}

Hg-oxidation activity of cerium oxide-based catalysts has also been reported in the literature [35,58]. The significant $\mathrm{Hg}^{\text {el }}$ to $\mathrm{Hg}^{\text {ox }}$ conversion activity of $\mathrm{CeO}_{2}$-based catalysts may be due to the high oxygen storage capacity of $\mathrm{CeO}_{2}$. Wen et al. [35] studied the chemisorption of $\mathrm{Hg}^{\mathrm{el}}$ by $\mathrm{CeO}_{2} / \gamma-\mathrm{Al}_{2} \mathrm{O}_{3}$ 
in the absence of $\mathrm{HCl}$ from the gaseous phase. The sorption capacity increased from 150 to $350{ }^{\circ} \mathrm{C}$ and then decreased at higher temperatures. The presence of $\mathrm{SO}_{2}$ and $\mathrm{H}_{2} \mathrm{O}$ in the gas inhibited the adsorption of mercury. At higher temperatures, $\mathrm{Ce}\left(\mathrm{SO}_{4}\right)_{2}$ is formed on the surface, preventing the contact between gaseous $\mathrm{Hg}^{\mathrm{el}}$ and $\mathrm{CeO}_{2}$ active sites. $\mathrm{Li}$ et al. [58] investigated the catalytic properties of the $\mathrm{CeO}_{2} / \mathrm{TiO}_{2}$ system in $\mathrm{HCl}, \mathrm{NO}$, and $\mathrm{SO}_{2}$ containing simulated flue gases. A fairly high $\mathrm{CeO}_{2} / \mathrm{TiO}_{2}$ mass ratio of 1.5 considerably improved oxidation efficiency. Oxidation activity increased with rising temperatures from 120 to $250{ }^{\circ} \mathrm{C}$, and then decreased at higher temperatures up to $400{ }^{\circ} \mathrm{C}$. At this temperature almost no oxidation activity remained. $\mathrm{HCl}$ in the gas phase considerably increased the activity in the presence of oxygen. $\mathrm{NO}$ and $\mathrm{SO}_{2}$ in the flue gas were found to have positive effects on $\mathrm{Hg}^{\mathrm{el}}$ oxidation [58]. In a subsequent paper, $\mathrm{Li}$ et al. [26] investigated the $\mathrm{Hg}^{\mathrm{el}}$ oxidation activity of $\mathrm{TiO}_{2}$ supported $\mathrm{Mn}-\mathrm{Ce}$ mixed oxides under simulated low-rank coal combustion flue gas. Oxidation activity increased with temperature from 120 to $250{ }^{\circ} \mathrm{C}$, and then dramatically decreased when the temperature reached $300{ }^{\circ} \mathrm{C}$. Significant $\mathrm{Hg}$ desorption was observed in the $250-300{ }^{\circ} \mathrm{C}$ range. $\mathrm{NH}_{3}$ reduced the $\mathrm{Hg}$ oxidation activity by competing with $\mathrm{Hg}^{\mathrm{el}}$ for the active sites or/and by consuming the surface oxygen which was responsible for $\mathrm{Hg}$ oxidation. Once the $\mathrm{NH}_{3}$ was cut off, $\mathrm{Hg}$ oxidation activity completely recovered in the presence of $\mathrm{O}_{2}$.

It was noted that the $\mathrm{Ce}^{3+}$ containing catalyst promoted the oxidation of $\mathrm{NO}$ to $\mathrm{NO}_{2}$ and also of $\mathrm{SO}_{2}$ to $\mathrm{SO}_{3}$. These side reactions are of importance in combustion systems and should be considered during further development of this catalyst system. $\mathrm{Hg}^{\mathrm{el}}$ oxidation performance was explained with a Langmuir-Hinshelwood mechanism. In this mechanism, an active surface species reacts with adsorbed mercury. $\mathrm{HCl}$ reacts to a certain degree with the active component $\mathrm{CeO}_{2}$. However, mercury oxidation proceeded also in the absence of $\mathrm{HCl}$ from the gaseous phase [58].

\subsection{Various Metal Based Catalysts}

Several other metal oxide and mixed metal oxide-based catalysts were developed as potential $\mathrm{Hg}$ capture and oxidation materials [22,59-61]. $\mathrm{SiO}_{2}-\mathrm{TiO}_{2}$ nano-composite was found to oxidize and capture $\mathrm{Hg}^{\mathrm{el}}$ under $\mathrm{UV}$ light at $135{ }^{\circ} \mathrm{C} . \mathrm{HCl}$ and $\mathrm{SO}_{2}$ positively affected $\mathrm{Hg}$ oxidation and capture activity [60]. A more recent study by $\mathrm{Li}$ et al. [61] investigated the $\mathrm{Hg}$ oxidation and capture potential of a $\mathrm{SiO}_{2}-\mathrm{TiO}_{2}-\mathrm{V}_{2} \mathrm{O}_{5}$ catalyst under simulated low-rank coal combustion flue gas. The $\mathrm{TiO}_{2}$ content was varied between 6-18 wt.-\%, while the $\mathrm{V}_{2} \mathrm{O}_{5}$ was kept at 5 wt.-\%. Hg oxidation activity decreased as the temperature increased from 135 to $300{ }^{\circ} \mathrm{C}$. However, an increase in $\mathrm{Hg}$ oxidation under SCR conditions was observed as the $\mathrm{TiO}_{2}$ content increased up to $18 \mathrm{wt} .-\%$. In the presence of $\mathrm{O}_{2}$, the flue gas components $\mathrm{HCl}, \mathrm{SO}_{2}$ and $\mathrm{NO}$ exhibited a positive effect on $\mathrm{Hg}$ oxidation.

In an experiment conducted by Lee and Bae [59], $\mathrm{Hg}^{\mathrm{el}}$ was completely adsorbed and oxidized by a high surface area $10 \mathrm{wt} .-\% \mathrm{~V}_{2} \mathrm{O}_{5} / \mathrm{TiO}_{2}$ aerogel at $100-200{ }^{\circ} \mathrm{C}$ temperature range. With an increase in temperature to $300{ }^{\circ} \mathrm{C}$, mercury started to desorb from the aerogel surface. The amount of $\mathrm{Hg}^{\text {el }}$ desorbed was higher as temperatures reached $500{ }^{\circ} \mathrm{C}$.

\subsection{Summary}

The halogens content of flue gases strongly influences $\mathrm{Hg}$ oxidation activity in the transition metal systems which otherwise tend to chemisorb mercury at temperatures below $200{ }^{\circ} \mathrm{C} . \mathrm{SO}_{2}$ reacts with 
transition metal active sites forming metal sulfates, thereby potentially deactivating the catalyst. In this way $\mathrm{SO}_{2} / \mathrm{SO}_{3}$ conversion is promoted by some transition metal oxides. Not much is known on the effect of $\mathrm{Hg}$-oxidation-active transition metal oxides on the $\mathrm{NO} / \mathrm{NO}_{2}$ conversion. Both conversion reactions are undesirable under combustion flue gas conditions. From the research conducted so far, it is obvious that pure transition metal oxides will not be suitable mercury oxidation catalysts for a flue gas environment. These catalysts must be modified in order to be suitable for flue gas environment applications.

\section{Mercury Oxidation on SCR Catalysts}

SCR catalysts are employed for the reduction of nitrogen oxides $\left(\mathrm{NO}_{\mathrm{x}}\right)$ in the presence of ammonia $\left(\mathrm{NH}_{3}\right)$ at temperatures higher than $300{ }^{\circ} \mathrm{C}$ if $\mathrm{SO}_{2}$ is present. The catalyst consists of a porous titanium dioxide monolithic substrate on which vanadium pentoxide $\left(\mathrm{V}_{2} \mathrm{O}_{5}\right)$, tungsten trioxide $\left(\mathrm{WO}_{3}\right)$ or molybdenum trioxide $\left(\mathrm{MoO}_{3}\right)$ is dispersed [68]. Besides $\mathrm{NO}_{\mathrm{x}}$ reduction, SCR catalysts are also active in the oxidation of volatile organic compounds [69,70]. In an additional side reaction, SCR catalysts also convert gaseous $\mathrm{Hg}^{\mathrm{el}}$ to $\mathrm{Hg}^{\text {ox }}$, particularly in the presence of $\mathrm{HCl}[21,23,25,71]$. Currently, SCR catalysts are being developed as multi-pollutant control devices.

In this section, several aspects regarding $\mathrm{Hg}^{\mathrm{el}}$ oxidation on SCR catalysts will be evaluated. The influence of flue gas components (halogens/hydrogen halides, $\mathrm{NH}_{3}, \mathrm{SO}_{2} / \mathrm{SO}_{3}, \mathrm{NO}_{\mathrm{x}}$ ), composition of the SCR catalysts and temperature will be considered first. The role of flue gas species on deactivation of SCR catalysts for mercury oxidation reaction will be covered as well. A brief discussion on mechanistic pathways and modeling of $\mathrm{Hg}^{\mathrm{el}}$ oxidation over SCR catalysts will follow. Modifications of SCR catalysts for achieving high $\mathrm{Hg}^{\text {el }}$ oxidation performance are of interest as well.

In order to determine their efficiency in oxidizing $\mathrm{Hg}^{\mathrm{el}}$ from flue gases, the SCR catalysts were tested at in the laboratory and in pilot [71-74] and full scale conditions(e.g., [75]). Some of these $\mathrm{Hg}^{\text {el }}$ oxidation results are presented in Table 3. Operating conditions and flue gas composition are also given in the table.

\subsection{Mercury Adsorption on SCR-Catalysts}

$\mathrm{Hg}$ adsorption on catalyst surfaces has been mentioned in a number of studies $[25,72,73] . \mathrm{Hg}^{\mathrm{el}}$ adsorption on the SCR catalyst surface was only observed in the absence of $\mathrm{HCl}[76,77]$. When $\mathrm{HCl}$ or $\mathrm{NH}_{3}$ was added to the simulated flue gas, a rapid mercury desorption was observed $[23,76,77]$. Eswaran and Stenger [76] also reported strong $\mathrm{Hg}$ adsorption in the presence of $\mathrm{H}_{2} \mathrm{SO}_{4}$. $\mathrm{Hg}^{\text {el }}$ adsorption slightly increased when $\mathrm{SO}_{2}$ was present [73]. Straube et al. [73] investigated the effect of different parameters on $\mathrm{Hg}$ adsorption on SCR catalysts under tail-end conditions (low $\mathrm{HCl}$ and $\mathrm{SO}_{2}$ concentration). They suggested that mercury adsorption involved chemisorption and the formation of $\mathrm{Hg}-\mathrm{O}$ bonding on the SCR catalyst surface. Another interesting finding was the observed link between the $\mathrm{V}_{2} \mathrm{O}_{5}$ content and the $\mathrm{Hg}$ adsorption extent on the SCR catalysts. In this case, $\mathrm{Hg}$ adsorption increased with increasing $\mathrm{V}_{2} \mathrm{O}_{5}$ content from 2.5 to $4.5 \mathrm{wt} \%$ [73]. 
Table 3. Elemental mercury oxidation on SCR-DeNOx catalysts.

\begin{tabular}{|c|c|c|c|c|c|c|c|c|c|c|c|c|}
\hline & \multicolumn{8}{|c|}{ Gas composition } & \multirow[b]{2}{*}{$\begin{array}{l}\mathrm{T}, \\
{ }^{\circ} \mathrm{C}\end{array}$} & \multirow{2}{*}{$\begin{array}{c}\text { Space } \\
\text { velocity, } \\
\mathrm{h}^{-1}\end{array}$} & \multirow{2}{*}{$\begin{array}{c}\mathbf{H g}^{\mathrm{el}} \\
\text { oxidation, } \\
\% \\
\end{array}$} & \multirow[b]{2}{*}{ Reference } \\
\hline & $\begin{array}{c}\mathrm{O}_{2} \\
\text { vol.\% } \\
\end{array}$ & $\begin{array}{c}\mathrm{H}_{2} \mathrm{O} \\
\text { vol. } \% \\
\end{array}$ & $\begin{array}{l}\mathrm{HCl} \\
\mathrm{ppm}\end{array}$ & $\begin{array}{l}\mathrm{NO} \\
\mathrm{ppm}\end{array}$ & $\begin{array}{l}\mathrm{NH}_{3} \\
\mathrm{ppm} \\
\end{array}$ & $\begin{array}{l}\mathrm{SO}_{2} \\
\text { ppm }\end{array}$ & $\begin{array}{l}\mathrm{SO}_{3} \\
\mathrm{ppm}\end{array}$ & $\begin{array}{c}\mathrm{Hg}^{\mathrm{el}} \\
\mu \mathrm{g} / \mathrm{Nm}^{3}\end{array}$ & & & & \\
\hline \multirow{2}{*}{ Lab scale } & 6 & - & 50 & 400 & 400 & - & - & $36-39$ & 350 & 4000 & $3-91$ & {$[25]$} \\
\hline & 6 & 8 & $0-35$ & 400 & 360 & 1000 & - & $10-20$ & 371 & 4000 & $12-70$ & {$[76]^{\bullet}$} \\
\hline \multirow{3}{*}{$\begin{array}{l}\text { (simulated } \\
\text { flue gases) }\end{array}$} & 5 & 1.8 & $0-20$ & 150 & - & 500 & - & 30 & 350 & $72^{\bullet}$ & $70-90$ & {$[3]$} \\
\hline & 3 & - & $10-50$ & 500 & 500 & - & - & 50 & $250-350$ & $120^{\circ}$ & $85-98$ & {$[78]$} \\
\hline & 3 & 8 & $5-35$ & 400 & 360 & - & - & $\sim 20$ & 390 & 3600 & $40-86$ & {$[79]^{\boldsymbol{\bullet}, * *}$} \\
\hline \multirow{4}{*}{$\begin{array}{c}\text { Bench scale } \\
\text { (simulated } \\
\text { flue gases) }\end{array}$} & - & 15 & $0.3-3$ & 400 & 300 & 70 & - & 160 & $260-320$ & $170^{\circ}$ & $50-90$ & {$[73]$} \\
\hline & 6 & 8 & $0-50$ & 600 & 550 & $0-2000$ & $0-50$ & 13 & 343 & \multirow{3}{*}{$\begin{array}{l}2609 \\
2000 \\
4000\end{array}$} & $20-71$ & {$[72]$} \\
\hline & 3.5 & 5.3 & $0-204$ & 350 & 315 & $280-2891$ & - & 19 & 350 & & $0->90$ & {$[77]$} \\
\hline & 7.1 & 6.8 & $0-20$ & 200 & 180 & 500 & - & $20-25$ & $350-400$ & & $30-88$ & {$[80]$} \\
\hline \multirow{2}{*}{$\begin{array}{l}\text { Pilot scale } \\
\text { (flue gases) }\end{array}$} & $2.7-4.4$ & - & 246 & 960 & 765 & $222-2921$ & - & $5-10$ & $300-400$ & 2943 & $9-20$ & {$[74]$} \\
\hline & 3 & - & 500 & 250 & 275 & 2000 & 50 & 120 & $300-350$ & 1800 & $<80$ & {$[71] *$} \\
\hline
\end{tabular}

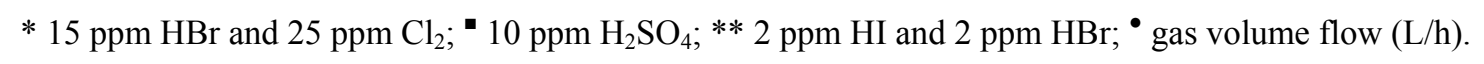




\subsection{Influence of Flue Gas Constituents}

Laboratory-scale studies proved that the activity of SCR catalysts for $\mathrm{Hg}^{\mathrm{el}}$ oxidation under simulated flue gas conditions is strongly linked to the halide species present and their concentrations $[3,21,23,53,71,78,80]$. Since $\mathrm{HCl}$ is the dominant halide species in flue gases, $\mathrm{Hg}^{\text {el }}$ oxidation is considered to proceed according to the following overall equation:

$$
\mathrm{Hg}_{(\mathrm{g})}+2 \mathrm{HCl}_{(\mathrm{g})}+0.5 \mathrm{O}_{2} \rightarrow \mathrm{HgCl}_{2(\mathrm{~g})}+\mathrm{H}_{2} \mathrm{O}_{(\mathrm{g})}
$$

He et al. [23] reported $\mathrm{Hg}^{\mathrm{el}}$ adsorption and oxidation over an $\mathrm{HCl}$ pretreated SCR catalyst. When a $\mathrm{Hg}^{\mathrm{el}} / \mathrm{N}_{2}$ gas mixture was passed over an untreated SCR catalyst, no obvious $\mathrm{Hg}^{\mathrm{el}}$ adsorption or oxidation was observed. The authors suggested that in a pure $\mathrm{N}_{2}$ environment at $300{ }^{\circ} \mathrm{C}$, the physical adsorption of $\mathrm{Hg}^{\mathrm{el}}$ on catalyst surface was weak. Adsorption and a certain degree of oxidation were recorded when employing the $\mathrm{HCl}$ pretreated catalyst, suggesting that adsorbed $\mathrm{HCl}$ reacted with adsorbed $\mathrm{Hg}^{\text {el }}$ to form $\mathrm{Hg}^{\text {ox }}$. Evidence of $\mathrm{HCl}$ adsorption on SCR catalyst surface was obtained by employing XPS $[23,25]$ and FT-IR $[23,24]$ surface analysis methods. $\mathrm{HCl}$ might also react with the active component $\mathrm{V}_{2} \mathrm{O}_{5}$ of the SCR catalyst. Several oxychloride complexes such as $\mathrm{VOCl}_{2}$, $\mathrm{V}_{2} \mathrm{O}_{3}(\mathrm{OH})_{2} \mathrm{Cl}_{2}, \mathrm{VO}_{2} \mathrm{Cl}_{2}[23,24]$ might be formed on the SCR-DeNOx catalyst surface.

Enhancement of $\mathrm{Hg}^{\mathrm{el}}$ oxidation activity was observed as $\mathrm{HCl}$ concentrations increased from 1 to $50 \mathrm{ppm}$ [72]. An increase in $\mathrm{Hg}$ oxidation with increasing $\mathrm{HCl}$ concentrations was also mentioned by Kamata et al. [21]. Actually, many reports discuss the $\mathrm{HCl}$ influence on SCR catalyst efficiency in oxidizing $\mathrm{Hg}^{\mathrm{el}}$. For this aim, $\mathrm{HCl}$ concentrations were varied within the $0-500 \mathrm{ppm}$ range (see Table 3).

Yang and Pan [81] investigated $\mathrm{Hg}^{\mathrm{el}}$ oxidation on SCR full-scale units as a function of coal-chloride content. When coal-chloride content fell below 100 ppm (below 10 ppmv HCl in flue gas), the $\mathrm{Hg}^{\mathrm{el}}$ oxidation was lower than $10 \%$. For coals containing over $800 \mathrm{ppm}$ chloride (approximately $80 \mathrm{ppmv} \mathrm{HCl}$ in flue gas), the $\mathrm{Hg}^{\text {el }}$ oxidation leveled off at $60-80 \%$. The pilot scale study by Lee et al. [74] also suggests that $\mathrm{Hg}^{\mathrm{el}}$ oxidation across SCR units is coal-type/composition dependent.

Eswaran and Stenger [79] employed honeycomb and plate-like SCR catalysts to investigate the effect of $\mathrm{HCl}, \mathrm{HBr}$ and $\mathrm{HI}$ on $\mathrm{Hg}^{\text {el }}$ oxidation in a lab-scale reactor. Compared to $\mathrm{HCl}, \mathrm{HBr}$ and $\mathrm{HI}$ added in small amounts ( $2 \mathrm{ppm}$ ) had a stronger effect on $\mathrm{Hg}$ oxidation (over $85 \%$ ). The authors noted that in the presence of $\mathrm{HBr}$, a large amount of $\mathrm{Hg}^{\text {ox }}$ was retained on the catalyst surface, while $\mathrm{HI}$ caused the previously retained mercury to desorb from the catalyst surface.

Pilot-scale results obtained by Cao et al. [82] revealed that, in the presence of different commercial SCR catalysts and under PRB (power river basin coal with low sulfur and chlorine contents) coal-derived flue gases, $\mathrm{Hg}^{\text {el }}$ oxidation was enhanced by the addition of hydrogen halides in the following order: $\mathrm{HBr}, \mathrm{HI}$, and $\mathrm{HCl}$ or $\mathrm{HF}$. However, it must be considered that the measurement of $\mathrm{Hg}^{\mathrm{el}}$ and $\mathrm{Hg}^{\mathrm{ox}}$ by the authors might have been hampered by the presence of $\mathrm{HBr}$ and $\mathrm{HI}$ in the flue gas.

A large number of studies mentioned the negative effect of $\mathrm{NH}_{3}$ addition on $\mathrm{Hg}^{\text {el }}$ oxidation by SCR catalysts in the presence of $\mathrm{HCl}$ and $\mathrm{NO}_{\mathrm{x}}$ [21,25,78,83]. Hong et al. [78] observed that increasing the $\mathrm{NH}_{3} / \mathrm{NO}$ ratio led to a decrease in $\mathrm{Hg}^{\text {el }}$ oxidation activity of SCR catalysts at $350{ }^{\circ} \mathrm{C}$. Eswaran and Stenger [76] explained the decrease in $\mathrm{Hg}^{\mathrm{el}}$ oxidation by the fact that $\mathrm{NH}_{3}$ caused $\mathrm{Hg}^{\mathrm{el}}$ to desorb from the SCR catalyst surface. Eom et al. [25] suggests that the decrease in $\mathrm{Hg}^{\mathrm{el}}$ oxidation in the presence of 
$\mathrm{NH}_{3}$ is caused by the adsorption of both $\mathrm{Hg}^{\mathrm{el}}$ and $\mathrm{NH}_{3}$ on the same active sites, and the reaction rate of $\mathrm{NH}_{3}$ is much faster than the reaction rate of $\mathrm{Hg}^{\mathrm{el}}$.

$\mathrm{SO}_{2}$ and $\mathrm{SO}_{3}$ in the flue gases are known to affect $\mathrm{Hg}^{\mathrm{el}}$ oxidation by SCR catalysts $[71-73,76]$. The results obtained by Zhuang et al. [72] indicated that $\mathrm{SO}_{2}$ and $\mathrm{SO}_{3}$ had a mitigating effect on $\mathrm{Hg}^{\text {el }}$ oxidation by SCR catalysts in the presence of $\mathrm{HCl}$. This behavior was attributed to the competitive adsorption of $\mathrm{SO}_{2}, \mathrm{SO}_{3}$ and $\mathrm{HCl}$ on the $\mathrm{SCR}$ catalyst surface active sites [72]. Also, Cao et al. [71] observed that $\mathrm{Hg}^{\text {el }}$ oxidation decreased once the $\mathrm{SO}_{2}$ concentration in the flue gas was increased. On the other hand, they observed that $\mathrm{Hg}^{\text {el }}$ oxidation increased with increasing the $\mathrm{SO}_{3}$ content to a maximum of $50 \mathrm{ppm}$ [71]. The addition of $\mathrm{H}_{2} \mathrm{SO}_{4}$ to a simulated flue gas increased the $\mathrm{Hg}$ oxidation activity of a commercial SCR catalyst, especially in the presence of $\mathrm{HCl}$ [76]. A strong adsorption of $\mathrm{Hg}^{\text {ox }}$ on the catalyst was determined to occur in the presence of $\mathrm{HCl}$ and $\mathrm{SO}_{3}$.

\subsection{Influence of Catalyst Composition, Temperature and Space Velocity}

The vanadium content of SCR catalysts affects $\mathrm{Hg}$ oxidation capacity as well. Higher vanadium content leads to a higher oxidation activity. One study reported $\mathrm{Hg}^{\text {el }}$ oxidation of $90 \%$ when vanadium content was 1.1-1.2 wt.- $\%$ and less than $40 \%$ when the content was 0.5 wt.- $\%$ [3]. Kamata et al. [24] observed an increase in $\mathrm{Hg}^{\mathrm{el}}$ oxidation almost linearly with $\mathrm{VO}_{\mathrm{x}}$ loadings up to $10 \mathrm{wt} . \mathrm{\%}$.

Vanadia-based SCR catalysts were tested at temperatures above $300{ }^{\circ} \mathrm{C}$, temperatures which are consistent with the SCR conditions in coal fired power plants. However, it was observed that high temperatures could limit the extent of $\mathrm{Hg}^{\text {el }}$ oxidation [73,84], most likely due to the desorption of mercury from the catalyst surface [59]. In a pilot-scale study, Sibley et al. [84] observed that, in the presence of hydrochloric acid (100 ppmv), a decline of mercury oxidation occurred with increasing temperature. Other studies described a similar $\mathrm{Hg}$ oxidation activity loss with increasing flue gas temperature and space velocity [75,80,83]. A bench scale study by Lee et al. [80] on a honeycomb catalyst under simulated PRB coal combustion flue gas reported significant $\mathrm{Hg}^{\text {el }}$ oxidation activity loss (from 83 to $30 \%$ ) at $400{ }^{\circ} \mathrm{C}$ and $4000 \mathrm{~h}^{-1}$ space velocity compared to $88 \% \mathrm{Hg}$ oxidation at $350{ }^{\circ} \mathrm{C}$ and $2000 \mathrm{~h}^{-1}$ space velocity. On the other hand, in the presence of $10 \mathrm{ppm} \mathrm{H}_{2} \mathrm{SO}_{4}, 15 \mathrm{ppm} \mathrm{HCl}$ and $1000 \mathrm{ppm} \mathrm{SO}_{2}$ a higher $\mathrm{Hg}^{\mathrm{el}}$ oxidation was observed once the temperature increased from 340 to $370{ }^{\circ} \mathrm{C}[76]$.

\subsection{Loss of $\mathrm{Hg}^{\text {el }}$ Oxidation Activity}

Among other factors, long term $\mathrm{Hg}^{\mathrm{el}}$ oxidation activity of SCR catalysts is dependent on catalyst age. Kamata et al. [21] conducted a series of experiments aiming to clarify the aging process of SCR catalysts. Samples of catalysts which had been in service for different time periods as well fresh catalysts were employed. They observed a loss of $\mathrm{Hg}^{\mathrm{el}}$ oxidation activity as the operation time increased. This behavior was more pronounced as $\mathrm{NH}_{3}$ concentration increased. Also, the laboratory studies of Eswaran and Stenger [79] showed that $\mathrm{Hg}$ oxidation in the presence of $\mathrm{HCl}$ was affected by catalyst age, suggesting that catalyst activity diminishes with catalyst history (age and flue gas conditions encountered).

A major problem of SCR catalyst operations under high dust configuration is the loss of catalytic activity caused by fly ash clogging/fouling and/or chemical poisoning. At high-dust SCR reactor 
operating temperatures $\left(280-400{ }^{\circ} \mathrm{C}\right)$ the concentration of volatile metals and metalloids in flue gas is higher. The most common catalyst poisons include arsenic (As), selenium (Se), potassium (K), sodium $(\mathrm{Na})$, calcium $(\mathrm{Ca})$, phosphorus $(\mathrm{P})$ and sulfur trioxide $\left(\mathrm{SO}_{3}\right)$. Crocker et al. [85] studied the influence of fly ash components $(\mathrm{Ca}, \mathrm{Na})$ and gas phase species $\left(\mathrm{NH}_{3}, \mathrm{SO}_{2}\right.$ and $\left.\mathrm{P}\right)$ on $\mathrm{SCR}$ catalyst deactivation by the formation of sulfates and phosphates. Thermogravimetric analysis (TGA) results showed that higher temperatures led to higher sulfation rates. $\mathrm{NH}_{3}$ and $\mathrm{P}$ from flue gas enhanced sulfate and phosphate formation on SCR catalysts. Wan et al. [86] investigated the influence of alkali (earth) metal doping on $\mathrm{Hg}^{\mathrm{el}}$ oxidation by a $\mathrm{V}_{2} \mathrm{O}_{5}-\mathrm{WO}_{3} / \mathrm{TiO}_{2}$ catalyst. Over $90 \% \mathrm{Hg}^{\mathrm{el}}$ oxidation was achieved when using fresh catalysts in the $200-400{ }^{\circ} \mathrm{C}$ range. Alkali doping reduced the $\mathrm{Hg}^{\mathrm{el}}$ oxidation activity down to $70 \% . \mathrm{H}_{2} \mathrm{O}$ vapor had a strong inhibitory effect on $\mathrm{Hg}^{\mathrm{el}}$ oxidation by alkali-doped catalysts. The deactivation potential of alkali (earth) metals was associated with their basicity value and ordered as follows: $\mathrm{K}, \mathrm{Na} \sim \mathrm{Ca}, \mathrm{Mg}[86,87]$.

The DeNOx activity of SCR catalyst decays as gas phase arsenic oxide $\mathrm{As}_{2} \mathrm{O}_{3}$ reacts with $\mathrm{V}_{2} \mathrm{O}_{5}$ active sites [88-90]. A loss in $\mathrm{Hg}$ oxidation activity is most likely to occur in this case as well, since As poisoning reduces the number of $\mathrm{V}_{2} \mathrm{O}_{5}$ active sites. $\mathrm{MoO}_{3}$-containing catalysts are more resistant to poisoning by $\mathrm{As}_{2} \mathrm{O}_{3} . \mathrm{As}_{2} \mathrm{O}_{3}$ reacts preferentially with $\mathrm{MoO}_{3}$, thus mitigating the deactivation rate of $\mathrm{V}_{2} \mathrm{O}_{5}$ active sites [88].

\subsection{Mechanism}

One of the aims of recent studies is to elucidate the mechanism through which $\mathrm{Hg}^{\mathrm{el}}$ is oxidized on the SCR catalyst surface. The mercury oxidation mechanism has to consider the critical promotional impact of $\mathrm{HCl}$ and the inhibitory effect of ammonia (or the DeNOx reaction). Because of the impact of ammonia, mercury oxidation takes place mostly at the outlet of the SCR reactor after $\mathrm{NH}_{3}$ is consumed (see Figure 2).

Figure 2. Schematic of Nitrogen Oxides Reduction and Mercury Oxidation over a SCR Catalyst (adapted from [16]).

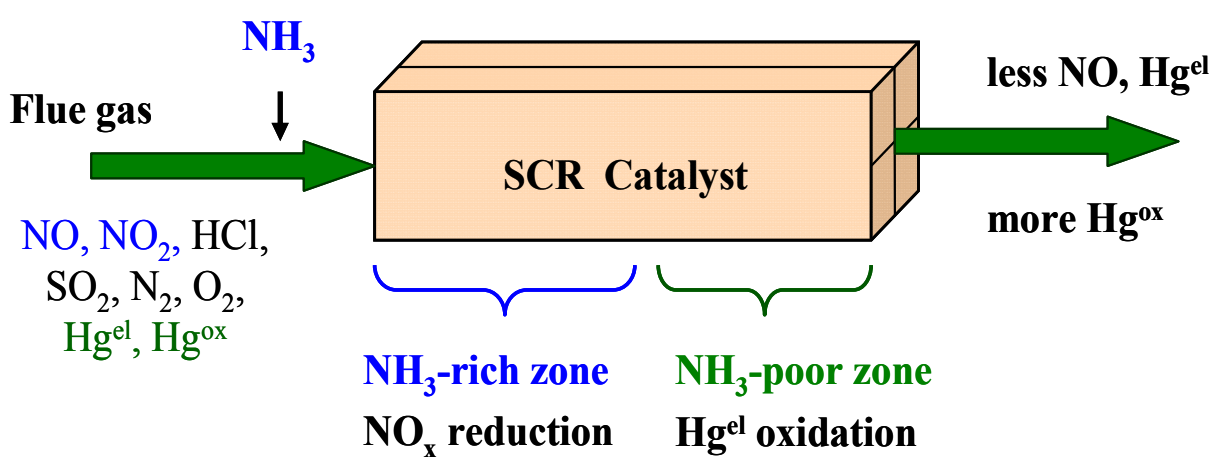

An early paper by Niksa and Fujiwara [20] proposed a model that is based on an Hg-oxidation mechanism in which $\mathrm{NH}_{3}$ and $\mathrm{HCl}$ species compete for the $\mathrm{V}_{2} \mathrm{O}_{5}$-active sites from the catalyst surface. The gaseous $\mathrm{Hg}^{\mathrm{el}}$ reacts with adsorbed $\mathrm{HCl}$, either from the gas-phase or as a weakly adsorbed species in an Eley-Rideal type of mechanism. This mechanism does not seem to be the most likely in the light of more recent findings. Senior [91] proposed a model based on an Eley-Rideal mechanism in which 
the adsorbed $\mathrm{Hg}^{\mathrm{el}}$ reacts with gaseous $\mathrm{HCl}$. According to the Senior model, $\mathrm{Hg}^{\mathrm{el}}$ competes with $\mathrm{NH}_{3}$ for $\mathrm{V}_{2} \mathrm{O}_{5}$ active sites.

The more recently proposed $\mathrm{Hg}$-oxidation mechanisms are based on the surface analysis conducted on SCR catalysts. Evidence of $\mathrm{HCl}$ and $\mathrm{Hg}^{\text {el }}$ adsorption onto the SCR catalyst surface active sites were recently given $[23,24,72,73]$. He et al. [23] proposed that $\mathrm{Hg}^{\mathrm{el}}$ oxidation over SCR catalysts occurs via a Langmuir-Hinshelwood mechanism. A similar mercury oxidation mechanism was proposed by Eom et al. [25]. According to the Langmuir-Hinshelwood mechanism, both $\mathrm{HCl}$ and $\mathrm{Hg}^{\mathrm{el}} \mathrm{species}$ are adsorbed onto the SCR catalysts active sites, followed by the formation of $\mathrm{HgCl}_{2}$ and its desorption from the catalyst surface.

Eom et al. [25] considered that $\mathrm{Hg}^{\mathrm{el}}$ oxidation proceeds with the reaction of gaseous $\mathrm{Hg}$ with vanadium oxychloride complexes from the catalyst surface, therefore a first layer of $\mathrm{Hg}(\mathrm{ads})$ is formed. Once the first layer is formed, the rest of the $\mathrm{Hg}$ from flue gas is adsorbed and reacts with chloride complexes from the catalyst surface to form multi-layers of $\mathrm{HgCl}_{2}$.

A recent theoretical study employed a DFT (density functional theory) method to investigate the reactivity of $\mathrm{V}_{2} \mathrm{O}_{5}$ surface towards $\mathrm{Hg}^{\mathrm{el}}, \mathrm{HCl}, \mathrm{HgCl}$ and $\mathrm{HgCl}_{2}$ [92]. The calculated adsorption energies indicated that adsorption of $\mathrm{Hg}^{\mathrm{el}}$ on the $\mathrm{V}_{2} \mathrm{O}_{5}$ surface was stronger than that of $\mathrm{HCl}$, therefore it is expected that the $\mathrm{Hg}^{\mathrm{el}}$ (ads) reacts with chlorine species to form an $\mathrm{HgCl}$ intermediate. $\mathrm{HgCl}$, strongly bound on the surface, further reacts with chlorine species to form $\mathrm{HgCl}_{2}$ (ads) which readily desorbs from the $\mathrm{V}_{2} \mathrm{O}_{5}$ surface.

The inhibition of $\mathrm{Hg}$ oxidation may be explained by the competitive adsorption of $\mathrm{HCl}$ and $\mathrm{NH}_{3}$ [25]. In this case, $\mathrm{NH}_{3}$ adsorption may dominate $\mathrm{HCl}$ adsorption on the active sites [21].

Some recent studies have reported reduction of $\mathrm{Hg}^{\mathrm{ox}}$ in the presence of $\mathrm{NH}_{3}$ [93,94]. The experimental results obtained by Madsen et al. [93] suggested that at temperatures higher than $325{ }^{\circ} \mathrm{C}$ a part of the $\mathrm{Hg}^{\text {ox }}$ was reduced back to $\mathrm{Hg}^{\text {el }}$ by $\mathrm{NH}_{3}$. Also, it was observed that VOC removal on SCR catalysts induced some $\mathrm{Hg}^{\mathrm{ox}}$ reduction [94].

$$
\mathrm{HgCl}_{2}+\mathrm{NH}_{3}+0.25 \mathrm{O}_{2} \rightarrow \mathrm{Hg}^{\mathrm{el}}+2 \mathrm{HCl}+0.5 \mathrm{~N}_{2}+0.5 \mathrm{H}_{2} \mathrm{O}
$$

\subsection{Optimization of $\mathrm{Hg}$ Oxidation Activity}

Improving the mercury oxidation activity of SCR-DeNOx catalysts is of interest for researchers in academia and industry. One of the ways for enhancing $\mathrm{Hg}$-oxidation activity is by applying/impregnating small quantities of metal oxides onto the SCR-DeNOx catalyst surface. Published studies reported results regarding $\mathrm{Hg}$-oxidation activity of $\mathrm{RuO}_{2} / \mathrm{SCR}$ [36], $\mathrm{CuO} / \mathrm{SCR}$, $\mathrm{NiO} / \mathrm{SCR}, \mathrm{ZnO} / \mathrm{SCR}$ [95].

It appears that the $\mathrm{RuO}_{2}$-modified SCR catalysts exhibit good $\mathrm{Hg}$-oxidation activity even in the presence of $\mathrm{NH}_{3}$ at $350{ }^{\circ} \mathrm{C}$. Hg-oxidation activity increased up to $90 \%$ with increased $\mathrm{Ru}$ loading up to 2 wt.-\%, and at a 2 to $12 \mathrm{ppm} \mathrm{HCl}$ content of the simulated flue gas [36]. Zeng et al. [95] investigated the $\mathrm{Hg}$-oxidation activity of a SCR catalyst impregnated with different metal oxides $\left(\mathrm{Cr}_{2} \mathrm{O}_{3}, \mathrm{ZnO}\right.$, $\mathrm{CuO}, \mathrm{NiO}, \mathrm{MnO}$ ). Under simulated flue gas conditions ( $4 \%$ by volume $\mathrm{O}_{2}, 7 \%$ by volume $\mathrm{H}_{2} \mathrm{O}$, $2000 \mathrm{mg} / \mathrm{m}^{3} \mathrm{SO}_{2}, 100 \mathrm{mg} / \mathrm{m}^{3} \mathrm{HCl}, \mathrm{NH}_{3} / \mathrm{NO}=400 \mathrm{ppm}$ and $390{ }^{\circ} \mathrm{C}$ ), the Hg-oxidation activity of the non-impregnated reference SCR catalyst was lower than $20 \%$. Under the same conditions, the oxidation efficiency of metal oxide-impregnated SCR catalysts increased up to $45 \%$. Experimental 
results showed that the $\mathrm{CuO}$ impregnated SCR catalyst exhibited the highest Hg-oxidation activity [95]. However, the investigation also showed that the activity improvement by metal oxides might not be stable in $\mathrm{SO}_{2}$-containing flue gases. $\mathrm{SO}_{2}$ present in the flue gas might react with the metal oxide active sites from the SCR surface forming metal sulfates, thereby causing a loss in mercury oxidation activity.

\subsection{Commercial Development}

The Babcock-Hitachi Company is currently offering a SCR catalyst with improved $\mathrm{Hg}^{\mathrm{el}}$ oxidation efficiency and a low $\mathrm{SO}_{2} / \mathrm{SO}_{3}$ conversion rate (below $0.5 \%$ ) under typical DeNOx operating conditions [96]. Kai and Kato [97] developed a plate-like honeycomb SCR catalyst in which a molybdenum-vanadium complex oxide $\mathrm{MoV}_{2} \mathrm{O}_{8}$ is the active compound for $\mathrm{Hg}^{\mathrm{el}}$ oxidation reaction. The Mo-V complex oxide coated on various inorganic porous carriers exhibits a relatively high $\mathrm{Hg}^{\text {el }}$ oxidation activity (above 72\%), and small $\mathrm{SO}_{2} / \mathrm{SO}_{3}$ conversion rate below $1 \%$. The catalyst also exhibits high $\mathrm{NO}_{\mathrm{x}}$ removal efficiency of approximately $98 \%$.

In their patent application, Nochi et al. [98] provided a method for producing a novel modified SCR-type $\mathrm{Hg}$ oxidation catalyst. The catalyst consists of $\mathrm{V}_{2} \mathrm{O}_{5}$ and $\mathrm{MoO}_{3}$ as active compounds supported on a $\mathrm{TiO}_{2}$ carrier. In catalyst formulation, one of the following elements is added: $\mathrm{W}, \mathrm{Cu}, \mathrm{Co}, \mathrm{Ni}, \mathrm{Zn}$. More than $82 \% \mathrm{Hg}$ oxidation can be achieved under typical high dust DeNOx plant conditions.

Several patents and patent applications discuss the improvement of vanadium-based catalysts for high Hg oxidation activity. For example, the addition of iridium Ir [99], manganese compound [100], silver halide [101] to the vanadium based-catalyst composition is expected to improve their reactivity towards $\mathrm{Hg}$ oxidation reaction.

\subsection{Summary}

Mercury oxidation activity of SCR catalysts is nowadays regarded as an important co-benefit of SCR systems in coal fired power plants.

The activity of SCR catalysts is correlated with boiler operating conditions and flue gas chemistry. Based on pilot and full scale data, several side approaches to maximize $\mathrm{Hg}^{\text {el }}$ oxidations have been suggested [83]. Increasing halide/(chlorine) content of the flue gases is one of them. When low chlorine coals are burned, the resulting $\mathrm{HCl}$ content in the flue gas is low; therefore low $\mathrm{Hg}^{\text {el }}$ oxidations are achieved. By blending low chlorine coal with high chlorine coal or by injecting different halogen containing additives (e.g., $\mathrm{NH}_{4} \mathrm{Cl}, \mathrm{CaCl}_{2}, \mathrm{Br}_{2}$, etc) into the flue gas [102-104] or by adding bromide salts to the coal [15], a higher $\mathrm{Hg}^{\mathrm{el}}$ oxidation could be obtained.

The conversion of $\mathrm{SO}_{2}$ to $\mathrm{SO}_{3}$ over $\mathrm{SCR}$ catalysts is a major problem. Therefore, the vanadium content of a SCR catalyst has to be limited in order to mitigate the $\mathrm{SO}_{2} / \mathrm{SO}_{3}$ reaction rate. However, the $\mathrm{Hg}^{\mathrm{el}}$ oxidation rate will also decrease if the vanadium content decreases [3].

Operating the SCR catalyst in the tail-end configuration, where the $\mathrm{SO}_{2}$ concentrations of the flue gas are low, would allow the use of higher vanadium contents and would benefit mercury oxidation. However, the $\mathrm{HCl}$ contents are in most cases low, thereby severely inhibiting the $\mathrm{Hg}$ oxidation rate. Operating the SCR catalysts at lower temperatures could improve oxidation activity, since it has been reported that higher temperatures inhibit $\mathrm{Hg}^{\mathrm{el}}$ oxidation $[83,84]$. 
Even though the amount of research regarding $\mathrm{Hg}$ oxidation on SCR catalysts has considerably increased over the past five years, further investigations are necessary for a better understanding of the role of flue gas components and the mechanism of $\mathrm{Hg}^{\mathrm{el}}$ oxidation. Also, the development and industrial implementation of SCR catalysts with high $\mathrm{Hg}$ oxidation activity are of great importance and intensively investigated.

\section{Novel Catalytic Methods for Mercury Oxidation in Flue Gases}

Besides the development of conventional catalysts for $\mathrm{Hg}^{\mathrm{el}}$ oxidation in flue gases, researchers are also investigating and implementing novel methods to achieve the same goal. Over recent years, various processes, such as photo-catalytic oxidation [105-107] and membrane delivery with catalytic oxidation [108], have been presented as possible alternatives to traditional catalytic oxidation methods.

Among the recently developed methods, the photo-catalytic oxidation of $\mathrm{Hg}^{\mathrm{el}}$ by UV $(\lambda=320-400 \mathrm{~nm})$-irradiated $\mathrm{TiO}_{2}$ surfaces has received a great deal of attention, since it can be performed even at room temperature. The aim of the experimental research was not only to study the photo-catalytic oxidation of $\mathrm{Hg}^{\mathrm{el}}$ but also to achieve new modified $\mathrm{TiO}_{2}$ structures $[22,60,105,107]$ which might exhibit greater effectiveness in oxidizing $\mathrm{Hg}^{\mathrm{el}}$ in flue gases. For instance, Jeon et al. [107] investigated the photo-catalytic ability of nanotitanosilicate fibers for oxidizing gas-phase $\mathrm{Hg}^{\text {el }} \mathrm{under}$ UV black light, fluorescent light and sunlight. The highest $\mathrm{Hg}^{\text {el }}$ oxidation activity (88\%) was achieved under fluorescent light. Wang et al. [105] investigated the $\mathrm{Hg}^{\mathrm{el}}$ oxidation by titania nanotubes with high surface area and porosity. More than $90 \% \mathrm{Hg}^{\text {el }}$ oxidation efficiency was achieved during a period of $100 \mathrm{~h}$. This mercury oxidation efficiency was due to the photo-catalyst structure as well the synergistic effect between the $\mathrm{Hg}^{\text {el }}$ oxidation and adsorption.

The proposed mechanistic pathway of $\mathrm{UV}^{-a s s i s t e d}$ photo-catalytic oxidation involves $\mathrm{HO}^{\bullet}$ radical formation by adsorption of $\mathrm{O}_{2}$ or $\mathrm{H}_{2} \mathrm{O}$ on the $\mathrm{TiO}_{2}$ surface. The $\mathrm{HO}^{\circ}$ radicals thus created readily react with adsorbed $\mathrm{Hg}^{\mathrm{el}}$ to form $\mathrm{HgO}[105,106]$. In order to gain a better understanding of the $\mathrm{Hg}^{\text {el }}$ photo-catalytic oxidation reaction, more experimental data is required. Also, the role of other flue gas constituents is of great interest.

Another innovative method, proposed by Guo et al. [108], for $\mathrm{Hg}^{\mathrm{el}}$ removal from flue gases is the membrane delivery catalytic oxidation system (MDCOs). The concept of MDCOs involves the use of an $\mathrm{Al}_{2} \mathrm{O}_{3}$ porous tubular membrane which serves as a carrier for the $\mathrm{MnO}_{\mathrm{x}} / \mathrm{Al}_{2} \mathrm{O}_{3}$ catalyst. The system combines the controlled delivery of oxidants (e.g., $\mathrm{HCl}$ ) with the catalytic oxidation of $\mathrm{Hg}^{\mathrm{el}}$. By employing this system, more than $90 \% \mathrm{Hg}^{\text {el }}$ oxidation was achieved in the $150-300{ }^{\circ} \mathrm{C}$ temperature range. The oxidation mechanism on MDCOs involves the reaction of adsorbed $\mathrm{Hg}^{\mathrm{el}}$ with adsorbed atomic chlorine $\left(\mathrm{Cl}^{\circ}\right)$ to form $\mathrm{HgCl}_{2}$.

Sorbent injection technology is promising for elemental and oxidized mercury removal from flue gases. Due to their ability to adsorb not only $\mathrm{Hg}^{\text {el }}[27,109,110]$, but also nitrogen oxide [111], sulfur dioxide [112,113] and/or hydrochloric acid [112], carbon-based materials promote elemental mercury oxidation. However, the aspects of carbon based materials used for $\mathrm{Hg}^{\text {el }}$ oxidation will not be covered in the present review.

The novel catalytic methods discussed above present a number of advantages as well as disadvantages compared with the traditional oxidation methods employed so far. For instance, when 
employing the MDCO system, high $\mathrm{Hg}^{\text {el }}$ oxidation efficiency is achieved with lower $\mathrm{HCl}$ consumption. Also, the inhibitory effect of $\mathrm{SO}_{2}$ seems to be less significant. However, the implementation of MCDO system at industrial scale requires an elaborate design.

The photo-catalytic oxidation of $\mathrm{Hg}^{\text {el }}$ is an attractive method since it can be performed even at room temperature and with high $\mathrm{Hg}^{\mathrm{el}}$ concentrations in the flue gas. The cost of $\mathrm{TiO}_{2}$ material is relatively low; however the cost of providing continuous UV light in a power plant configuration remains an issue. In power plants, large flue gas volumes have to be treated. The design of large photo-catalytic reactors is unexplored territory.

\section{Conclusions and Future Research}

Over the past six years a significant amount of research has been devoted to developing and implementing new catalysts for elemental mercury $\mathrm{Hg}^{\mathrm{el}}$ oxidation in flue gases. Academia and industry have focused their efforts towards this purpose. Research has been carried out at laboratory, pilot and full scale.

It is now known that the activity of almost all mercury oxidation catalysts studied so far depends on a certain concentration of $\mathrm{HCl}$ and $\mathrm{HBr}$ in the flue gases to be treated. The role of the hydrogen halides could be restricted to transforming the primary formed non-volatile $\mathrm{HgO}$ into the volatile $\mathrm{HgX}$. The halides could also be the source of chlorine and bromine atoms, the reactive intermediates which oxidize the elemental mercury. Most catalysts are not effective in flue gases from coals containing low levels of halogens.

SCR-DeNOx catalysts were intensively studied due to their potential as co-oxidation agents for $\mathrm{Hg}^{\text {el }}$. Ways for improving their $\mathrm{Hg}$ oxidation activity were proposed. Coating/impregnating the SCR monolith with different metals and metal oxides was reported to cause an increase in $\mathrm{Hg}$ oxidation activity. The latest reports on $\mathrm{RuO}_{2}$ addition to SCR catalyst seems to be promising in this respect.

Recently it was established by different research groups that SCR-catalysts can also reduce oxidized mercury back to the elementary valence state. This aspect has been overlooked so far and should be an integral part of future research. The prevention of reduction of oxidized mercury by catalysts will result in an increase of the overall oxidation activity of SCR-DeNOx catalysts.

The rate constant of mercury oxidation reaction on a standard commercial high-dust SCR-DeNOx catalyst is of the order of the DeNOx reaction. Therefore the mercury oxidation will take place in the upper layer of the porous catalyst. Consequently, the pore structure of catalysts will be of importance in the effort to optimize the oxidation activity for mercury.

Recently, some publications have discussed the likely pathways for mercury oxidation over SCR catalysts. $\mathrm{Hg}^{\text {el }}$ oxidation involves $\mathrm{V}_{2} \mathrm{O}_{5}$ active sites and $\mathrm{HCl}$ and $\mathrm{HBr}$ species. At this point, further research is necessary in order to gain a better understanding of the mechanistic pathways for both $\mathrm{Hg}$ oxidation and the role of other flue gas components. This will aid future catalyst development.

The laboratory-based research conducted so far showed that transition metal oxides are able to adsorb and oxidize $\mathrm{Hg}^{\mathrm{el}}$ in the presence of gaseous $\mathrm{HCl}$ or $\mathrm{HBr}$. The activity of these catalysts is affected by temperature, other flue gas components and metal loading. Langmuir-Hinshelwood and Mars-Maessen mechanisms were proposed for $\mathrm{Hg}$ oxidation over metal oxide catalysts. The $\mathrm{SO}_{2} / \mathrm{SO}_{3}$ and $\mathrm{NO} / \mathrm{NO}_{2}$ conversion ability has to be considered when implementing metal oxide based catalysts 
in full scale applications. Investigations so far have shown that transition metal oxides are prone to poisoning by $\mathrm{SO}_{2}$ in the flue gas.

Laboratory and pilot scale studies have centered on noble metal catalysts for mercury oxidation applications in flue gases. Noble metals have the ability to adsorb mercury on their surface. They might affect the undesired $\mathrm{SO}_{2} / \mathrm{SO}_{3}$ and $\mathrm{NO} / \mathrm{NO}_{2}$ conversion reaction. From this group, gold-based catalysts seem to be promising candidates. These catalysts are highly active even at low metal loadings $(1 \mathrm{wt} .-\%)$ and low temperatures $\left(<200{ }^{\circ} \mathrm{C}\right)$. Pilot scale studies showed that the gold based catalysts are not easily subjected to deactivation under flue gas conditions. Further investigation into the mechanism, the role of other flue gas components and temperature on mercury oxidation by gold catalysts are necessary.

Several new methods for catalytic oxidation of mercury from flue gases were proposed. UV-assisted oxidation by $\mathrm{TiO}_{2}$ nano-particles or fibers, catalytic membranes and dielectric barrier discharge are the proposed novel methods. However, at this stage the number of publications on these topics is relatively limited and these methods have a long way to go until they might be ready for industrial application.

\section{Acknowledgments}

The authors would like to thank Ion Balasanian from Gheorghe Asachi Technical University of Iasi, Romania, and Katharina Zeng from Martin-Luther University Halle-Wittenberg, Germany for their support.

Financial support through the European Union scholarship (Erasmus) funding is acknowledged.

\section{References}

1. Division of Technology, Industry and Economics (DTIE) Chemicals Branch. Study on Mercury Sources and Emissions and Analysis of the Cost and Effectiveness of Control Measures; UNEP: Geneva, Switzerland, 2010.

2. Pirrone, N.; Cinnirella, S.; Feng, X.; Finkelman, B.R.; Friedli, R.H.; Leaner, J.; Mason, R.; Mukherjee, B.A.; Stracher, G.; Streets, G.D.; Telmer, K. Mercury Fate and Transport in the Global Atmosphere-Emissions, Measurements and Models; Springer: New York, NY, USA, 2009.

3. Lee, B.J.; Lee, M.S.; Lee, Y.I. The characteristics of catalysts for mercury oxidation in thermal power plants. Proc. World Acad. Sci. Eng. Technol. 2008, 44, 256-257.

4. United States Environmental Protection Agency (U.S. EPA). Mercury News, December 2011. Available online: http://www.epa.gov/hg/ (accessed on 2 January 2012).

5. European Commission. Directive 2010/75/EU of the European Parliament and of the Council on industrial emissions (integrated pollution prevention and control). Off. J. Eur. Union 2010, L334, $17-117$.

6. Pavlish, J.H.; Sondreal, E.A.; Mann, D.M.; Olson, S.E.; Galbreath, C.K.; Laudal, L.; Benson, A.S. Status review of mercury control options for coal-fired power plants. Fuel Process. Technol. 2003, 82, 89-165. 
7. Pavlish, H.J.; Hamre, L.L.; Zhuang, Y. Mercury control technologies for coal combustion and gasification systems. Fuel 2010, 89, 838-847.

8. Schofield, K. Fuel-mercury combustion emissions: An important heterogeneous mechanism and an overall review of its implications. Environ. Sci. Technol. 2008, 42, 9014-9030.

9. Presto, A.A.; Granite, E.J. Survey of catalysts for oxidation of mercury in flue gas. Environ. Sci. Technol. 2006, 40, 5601-5609.

10. Wilhelm, S.M. Estimate of mercury emissions to the atmosphere from petroleum. Environ. Sci. Technol. 2001, 35, 4704-4710.

11. Yudovich, Y.E.; Ketris, M.P. Mercury in coal: A review. Part 2 coal use and environmental problems. Int. J. Coal Geol. 2005, 62, 136-165.

12. Sondreal, E.A.; Benson, S.A.; Pavlish, S.A.; Ralston, N.V.C. An overview of air quality III: Mercury, trace elements, and particulate matter. Fuel Process. Technol. 2004, 85, 425-440.

13. Vosteen, B.W. Native Halogens in Coals from US, China and Elsewhere-Low Chlorine Coal Need Bromide Addition for Effective Mercury Capture. In Proceedings of MEC7-Mercury Emissions from Coal-International Experts Workshop, Glasgow, UK, 16-18 June 2010.

14. Qiao, S.; Chen, J.; Li, J.; Qu, Z.; Liu, P.; Yan, N.; Jia, J. Adsorption and catalytic oxidation of gaseous elemental mercury in flue gas over $\mathrm{MnO}_{\mathrm{x}} /$ alumina. Ind. Eng. Chem. Res. 2009, 48, 3317-3322.

15. Vosteen, W.B.; Kanefke, R.; Köser, H. Bromine-enhanced mercury abatement from combustion flue gases-recent industrial applications and laboratory research. VGB PowerTech 2006, 86, 70-75.

16. Vosteen, W.B.; Straube, S.; Köser, H. Mercury Sorption and Mercury Oxidation by Chlorine and Bromine at SCR-DeNOx Catalysts_-Part A: Oxidation. In Proceedings of 9th Annual EPA, DOE, EPRI, EEI Conference on Clean Air, Global Warming \& Renewable Energy, Tucson, AZ, USA, 24-25 January 2006.

17. Lopez, N.; Gomez-Segura, J.; Marin, R.P.; Perez-Ramirez, J.P. Mechanism of HCl oxidation (Deacon process) over RuO2. J. Catal. 2008, 255, 29.

18. Bierögel, S.; Baltin, G.; Koeser, H. Important side reactions in DeNOx facilities-Investigation for halogen formation. Chem. Ing. Tech. 2003, 75, 1066-1067.

19. Griffin, R.D. A new theory of dioxin formation in municipal solid waste combustion. Chemophere 1986, 15, 1987-1990.

20. Niksa, S.; Fujiwara, N. A predictive mechanism for mercury oxidation on selective catalytic reduction catalyst under coal-derived flue gas. J. Air Waste Manag. Assoc. 2005, 55, 1866-1875.

21. Kamata, H.; Uueno, S.I.; Naito, T.; Yukimura, A. Mercury oxidation over the $\mathrm{V}_{2} \mathrm{O}_{5}\left(\mathrm{WO}_{3}\right) / \mathrm{TiO}_{2}$ commercial SCR catalyst. Ind. Eng. Chem. Res. 2008, 47, 8136-8141.

22. Li, Y.; Murphy, D.P.; Wu, C.Y.; Powers, W.K.; Bonzongo, J.C. Development of silica/vanadia/titania catalysts for removal of elemental mercury from coal-combustion flue gas. Environ. Sci. Technol. 2008, 42, 5304-5309.

23. He, S.; Zhou, J.; Zhu, Y.; Luo, Z.; Ni, M.; Cen, K. Mercury oxidation over a vanadia-based selective catalytic reduction catalyst. Energy Fuels 2009, 23, 253-259.

24. Kamata, H.; Uueno, S.I.; Naito, T.; Yamaguchi, A.; Ito, S. Mercury oxidation by hydrochloric acid over a $\mathrm{VO}_{\mathrm{x}} / \mathrm{TiO}_{2}$ catalyst. Catal. Commun. 2008, 9, 2441-2444. 
25. Eom, Y.; Jeon, H.S.; Ngo, A.T.; Kim, J.; Lee, G.T. Heterogeneous mercury reaction on a selective catalytic reduction (SCR) catalyst. Catal. Lett. 2008, 121, 219-225.

26. Li, H.; Wu, Y.C.; Li, Y.; Zhang, J. Superior activity of $\mathrm{MnO}_{\mathrm{x}}-\mathrm{CeO}_{2} / \mathrm{TiO}_{2}$ catalyst for catalytic oxidation of elemental mercury at low flue gas temperatures. Appl. Catal. B Environ. 2012, 111-112, 381-388.

27. Hu, C.; Zhou, J.; Luo, Z.; Cen, K. Oxidative adsorption of elemental mercury by activated carbon in simulated coal-fired flue gas. Energy Fuels 2011, 25, 154-158.

28. Granite, J.E.; Pennline, H.W.; Hargis A.R. Novel sorbents for mercury removal from flue gas. Ind. Eng. Chem. Res. 2000, 39, 1020-1029.

29. Hrdlicka, J.A.; Seames, W.S.; Mann, M.D.; Muggli, D.S.; Horabik, C.A. Mercury oxidation in flue gas using gold and palladium catalysts on fabric filters. Environ. Sci. Technol. 2008, 42, $6677-6682$.

30. Zhao, Y.; Mann, M.D.; Pavlish, J.H.; Mibeck, B.A.F.; Dunham, E.G.; Olson, E.S. Application of gold catalyst for mercury oxidation by chlorine. Environ. Sci. Technol. 2006, 40, 1603-1608.

31. Ji, L.; Sreekanth, M.P.; Smirniotis, G.P.; Thiel, W.S.; Pinto, G.N. Manganese oxide/Titania materials for removal of $\mathrm{NO}_{\mathrm{x}}$ and elemental mercury from flue gas. Energy Fuels 2008, 22, 2299-2306.

32. Yang, S.; Guo, Y.; Yan, N.; Wu, D.; He, H.; Qu, Z.; Jia, J. Elemental mercury capture from flue gas by magnetic Mn-Fe spinel: Effect of chemical heterogeneity. Ind. Eng. Chem. Res. 2011, 50, 9650-9656.

33. Liu, Y.; Wang, Y.; Wang, H.; Wu, Z. Catalytic oxidation of gas-phase mercury over $\mathrm{Co} / \mathrm{TiO}_{2}$ catalysts prepared by sol-gel method. Catal. Commun. 2011, 12, 1291-1294.

34. Kong, F.; Qui, J.; Liu, H.; Zhao, R.; Ai, Z. Catalytic oxidation of gas-phase elemental mercury by nano- $\mathrm{Fe}_{2} \mathrm{O}_{3}$. J. Environ. Sci. 2011, 24, 699-704.

35. Wen, X.; Li, C.; Fan, X.; Gao, H.; Zhang, W.; Chen, L.; Zeng, G.; Zhao, G. Experimental study of gaseous elemental mercury removal with $\mathrm{CeO}_{2} / \gamma-\mathrm{Al}_{2} \mathrm{O}_{3}$. Energy Fuels 2011, 25, 2939-2944.

36. Yan, N.; Chen, W.; Chen, J.; Qu, Z.; Guo, Y.; Yang, S.; Jinping, J. Significance of $\mathrm{RuO}_{2}$ modified SCR catalysts for elemental mercury oxidation in coal-fired flue gas. Environ. Sci. Technol. 2011, 45, 5725-5730.

37. Presto, A.A.; Granite, E.J. Noble Metal Catalysts for mercury oxidation in utility flue gas. Platin. Met. Rev. 2008, 52, 144-154.

38. Granite, J.E.; Pennline, H.W. Catalysts for oxidation of mercury in flue gases. U.S. Patent 7,776,780 B1, 17 August 2010.

39. Blythe, M.G.; Braman, C.; Dombrowski, K.; Machalek, T. Pilot Testing of Mercury Oxidation Catalysts for Upstream of Wet FGD Systems-Final Technical Report; Cooperative Agreement No. DE-FC26-04NT41992; DOE-NETL: Austin, TX, USA, 2010.

40. Blythe, M.G.; Paradis, J. Full-Scale Testing of a Mercury Oxidation Catalyst Upstream of a Wet FGD System, Final Technical Report; Cooperative Agreement No. DE-FC26-06NT42778; DOE-NETL: Austin, TX, USA, 2010.

41. Poulston, S.; Granite, J.E.; Pennline, W.H.; Myers, R.C.; Stanko, P.D.; Hamilton, H.; Rowsell, L.; Smith, J.W.A.; Ilkenhans, T.; Chu, W. Metal sorbents for high temperature mercury capture from fuel gas. Fuel 2007, 86, 2201-2203. 
42. Granite, J.E.; Pennline, H.W. Method for high temperature mercury capture from gas streams. U.S. Patent 7,033,419 B1, 25 April 2006.

43. Koutsopoulos, S.; Johannessen, T.; Eriksen, K.M.; Fehrmann, R. Titania-supported Pt and Pt-Pd nanoparticle catalysts for the oxidation of sulfur dioxide. J. Catal. 2006, 238, 206-213.

44. Ji, Y.; Toops, T.J.; Graham, U.M.; Jacobs, G.; Crocker, M. A kinetic and DRIFTS study of supported Pt catalysts for NO oxidation. Catal. Lett. 2006, 110, 29-37.

45. Bond, G.C.; Louis, C.; Thompson, D.T. Catalysis by Gold; Imperial College Press: London, UK, 2006.

46. Blythe, G.; Dombrowski, K.; Machalek, T.; Richardson, C.; Richardson, M. Pilot Testing of Mercury Oxidation Catalysts for Upstream of Wet FGD Systems, Final Report; Cooperative Agreement No. DE-FC26-01NT41185; DOE-NETL: Austin, TX, USA, 2006.

47. Blythe, G.; Miller, C.; Freeman, B.; Madrid, J. Full-scale demonstration of oxidation catalyst for enhanced mercury control by wet FGD. In Proceedings of Power Plant Air Pollutant Control “Mega” Symposium, Baltimore, MD, USA, 25-28 August 2008.

48. Richardson, C. Evaluation of MerCAP for Power Plant Mercury Control_Final Project Report for US Department of Energy-NETL; Cooperative Agreement No. DE-FC26-03NT41993; DOE-NETL: Austin, TX, USA, 2009.

49. Tao, F.M. A new approach to the efficient basis set for accurate molecular calculations: Applications to diatomic molecules. J. Chem. Phys. 1994, 100, 3645-3650.

50. Boreskov, G.K.; Slinko, M.G.; Volkova, E.I. Catalysis of the conversion of sulfur dioxide to sulfur trioxide by metals and platinum-gold alloys. Dokl. Akad. Nauk SSSR 1953, 92, 109-120.

51. Yamaguchi, A.; Akiho, H.; Ito, S. Mercury oxidation by copper oxides in combustion flue gases. Powder Technol. 2008, 180, 222-226.

52. Kamata, H.; Mouri, S.; Uueno, S.I.; Takano, K.; Watanabe, K.; Yamaguchi, A.; Ito, S. Mercury oxidation by hydrogen chloride over the $\mathrm{CuO}$ based catalysts. Stud. Surf. Sci. Catal. 2007, 172, 621-622.

53. Kim, H.M.; Ham, S.W.; Li, J.B. Oxidation of gaseous elemental mercury by hydrochloric acid over $\mathrm{CuCl}_{2} / \mathrm{TiO}_{2}$-based catalysts in SCR process. Appl. Catal. B Environ. 2010, 99, 272-278.

54. Miksche, J.S.; Ghorishi, B.S. Catalytic Oxidation of Elemental Mercury at Low Temperatures-Technical Paper. In Proceedings of 32nd International Technical Conference on Coal Utilization \& Fuel Systems, Clearwater, FL, USA, 10-15 June 2007.

55. Mei, Z.; Shen, Z.; Mei, Z.; Zhang, Y.; Xiang, F.; Chen, J.; Wang, W. The effect of N-doping and halide-doping on the activity of $\mathrm{CuCoO}_{4}$ for the oxidation of elemental mercury. Appl. Catal. B Environ. 2008, 78, 112-119.

56. Wu, S.; Ozaki, M.; Uddin, A.Md.; Sasaoka, E. Development of iron-based sorbents for $\mathrm{Hg}^{0}$ removal from coal derived fuel gas: Effect of hydrogen chloride. Fuel 2008, 87, 467-474.

57. Li, J.; Yan, N.; Qu, Z.; Qiao, S.; Yang, S.; Guo, Y.; Liu, P.; Jia, J. Catalytic oxidation of elemental mercury over the modified catalyst $\mathrm{Mn} / \alpha-\mathrm{Al}_{2} \mathrm{O}_{3}$ at lower temperatures. Environ. Sci. Technol. 2010, 44, 426-431.

58. Li, H.; Wu, Y.C.; Li, Y.; Zhang, J. $\mathrm{CeO}_{2}-\mathrm{TiO}_{2}$ catalysts for catalytic oxidation of elemental mercury in low-rank coal combustion flue gas. Environ. Sci. Technol. 2011, 45, 7394-7400. 
59. Lee, W.; Bae, G.N. Removal of elemental mercury $\mathrm{Hg}^{0}$ by nanosized $\mathrm{V}_{2} \mathrm{O}_{5} / \mathrm{TiO}_{2}$ catalysts. Environ. Sci. Technol. 2009, 43, 1522-1527.

60. Li, Y.; Murphy, P.; Wu, Y.C. Removal of elemental mercury from simulated coal-combustion flue gas using a $\mathrm{SiO}_{2}-\mathrm{TiO}_{2}$ nanocomposite. Fuel Process. Technol. 2008, 89, 567-573.

61. Li, H.; Li, Y.; Wu, Y.C.; Zhang, J. Oxidation and capture of elemental mercury over $\mathrm{SiO}_{2}-\mathrm{TiO}_{2}-\mathrm{V}_{2} \mathrm{O}_{5}$ catalysts in simulated low-rank coal combustion flue gas. Chem. Eng. J. 2011, 169, 186-193.

62. Ghorishi, S.B.; Lee, W.C.; Jozewicz, S.W.; Kilgroe, D.J. Effects of fly ash transition metal content and flue gas $\mathrm{HCl} / \mathrm{SO}_{2}$ ration on mercury speciation on waste combustion. Environ. Eng. Sci. 2005, 22, 221-231

63. Kamata, H.; Uueno, S.I.; Sato, N.; Naito, T. Mercury oxidation by hydrochloric acid over $\mathrm{TiO}_{2}$ supported metal oxide catalysts in coal combustion flue gas. Fuel Proc. Technol. 2009, 90, 947-951.

64. Mei, Z.; Shen, Z.; Zhao, Q.; Yuan, T.; Zhang, Y.; Xiang, F.; Wang, W. Removing and recovering gas-phase elemental mercury by $\mathrm{Cu}_{\mathrm{x}} \mathrm{Co}_{3-\mathrm{x}} \mathrm{O}_{4} 0.75 \leq \mathrm{x} \leq 2.25$, in the presence of sulphur compounds. Chemosphere 2008, 70, 1399-1404.

65. Yang, S.; Guo, Y.; Yan, N.; Wu, D.; He, H.; Xie, J.; Qu, Z.; Jia, J. Remarkable effect of the incorporation of titanium on the catalytic activity and $\mathrm{SO}_{2}$ poisoning resistance of magnetic Mn-Fe spinel for elemental mercury capture. Appl. Catal. B Environ. 2011, 101, 698-708.

66. Yang, S.; Guo, Y.; Yan, N.; Wu, D.; He, H.; Qu, Z.; Yang, C.; Zhou, Q.; Jia, J. Nanosized cation-deficient Fe-Ti spinel: A novel magnetic sorbent for elemental mercury capture from flue gas. Appl. Mater. Interfaces 2011, 3, 209-217.

67. Yang, S.; Yan, N.; Guo, Y.; Wu, D.; He, H.; Qu, Z.; Li, J.; Zhou, Q.; Jia, J. Gaseous elemental mercury capture from flue gas using magnetic nanosized $\left(\mathrm{Fe}_{3-\mathrm{x}} \mathrm{Mn}_{\mathrm{x}}\right)_{1-\delta} \mathrm{O}_{4}$. Environ. Sci. Technol. 2011, 45, 1540-1546.

68. Granger, P.; Parlvulescu, V.I. Past and Present in DeNOx Catalysis-From Molecular Modeling to Chemical Engineering; Elsevier: Amsterdam, The Netherlands, 2007.

69. Finocchio, E.; Baldi, M.; Busca, G.; Pistarino, C.; Romezzano, G.; Bregani, F.; Toledo, G.P. A study of the abatement of VOC over $\mathrm{V}_{2} \mathrm{O}_{3}-\mathrm{WO}_{3}-\mathrm{TiO}_{2}$ and alternative SCR catalysts. Catal. Today 2000, H59, 261-268.

70. Lazar, L.; Köser, H.; Balasanian, I.; Bandrabur, F. Catalytic destruction of aromatic VOCs on SCR-DeNOx commercial catalyst. Environ. Eng. Manag. J. 2007, 6, 13-20.

71. Cao, Y.; Chen, B.; Wu, J.; Cui, H.; Smith, J.; Chen, K.C.; Chu, P.; Pan, P.W. Study of mercury oxidation by a selective catalytic reduction catalyst in a pilot-scale slipstream reactor at a utility boiler burning bituminous coal. Energy Fuels 2007, 21, 145-156.

72. Zhuang, Y.; Laumb, J.; Liggett, R.; Holmes, M.; Pavlish, J. Impacts of acid gases on mercury oxidation across SCR catalyst. Fuel Process. Technol. 2007, 88, 929-934.

73. Straube, S.; Hahn, T.; Koeser, H. Adsorption and oxidation of mercury in tail-end SCR-DeNOx plants-Bench scale investigations and speciation experiments. App. Catal. B Environ. 2008, 79, 286-295. 
74. Lee, W.C.; Srivastava, K.R.; Ghorishi, B.S.; Kaewowski, J.; Hastings, W.T.; Hirschi, C.J. Pilot-scale study of the effect of selective catalytic reduction catalysts on mercury speciation in Illinois and Powder River Basin coal combustion flue gases. J. Air Waste Manag. Assoc. 2006, 56, 643-649.

75. Senior, C. Mercury oxidation across SCRs in coal-fired power plants. In Proceedings of Mercury Control Technology R\&D Program Review, Pittsburgh, PA, USA, 12-14 July 2005.

76. Eswaran, S.; Stenger, H.G. Understanding mercury conversion in selective catalytic reduction (SCR) catalysts. Energy Fuels 2005, 19, 2328-2334.

77. Lee, W.C.; Srivastava, K.R.; Ghorishi, B.S.; Hastings, W.T.; Stevens, M.F. Investigation of selective catalytic reduction impact on mercury speciation under simulated $\mathrm{NO}_{\mathrm{x}}$ emission control conditions. J. Air Waste Manag. Assoc. 2004, 54, 1560-1566.

78. Hong, J.H.; Ham, W.S.; Kim, H.M.; Lee, M.S.; Lee, B.J. Characteristics of commercial selective catalytic reduction catalysts for the oxidation of gaseous elemental mercury with respect to reaction conditions. Korean J. Chem. Eng. 2010, 27, 1117-1122.

79. Eswaran, S.; Stenger, H.G. Effect of halogens on mercury conversion in SCR catalysts. Fuel Process. Technol. 2008, 89, 1153-1159.

80. Lee, W.C.; Serre, D.S.; Zhao, Y.; Lee, J.S.; Hastings, W.T. Mercury oxidation promoted by a selective catalytic reduction catalyst under simulated powder river basin coal combustion conditions. J. Air Waste Manag. Assoc. 2008, 58, 484-493.

81. Yang, H.M.; Pan, W.P. Transformation of mercury speciation through the SCR system in power plants. J. Environ. Sci. 2007, 19, 181-184.

82. Cao, Y.; Gao, Z.; Zhu, J.; Wang, Q.; Huang, Y.; Chiu, C.; Parker, B.; Chu P.; Pan, W.P. Impacts of halogen addition in mercury oxidation, in a slipstream selective catalyst reduction (SCR), reactor when burning sub-bituminous coal. Environ. Sci. Technol. 2008, 42, 256-261.

83. Senior, C. Oxidation of Mercury Across SCR Catalysts in Coal-Fired Power Plants Burning Low Rank Fuels. Final Report to U.S. DOE/NETL; U.S. Department of Energy Agreement No. DE-FC26-03NT41728; Reaction Engineering International: Salt Lake City, UT, USA, 2004.

84. Sibley, F.A.; Dene, C.; Jimenez, A.; Hinton, W.S. Pilot scale studies on mercury oxidation by SCR catalyst. In Proceedings of Power Plant Air Pollutant Control "Mega" Symposium Symposium, Baltimore, MD, USA, 25-28 August 2008.

85. Crocker, R.C.; Benson, A.S.; Laumb, D.J. SCR catalyst blinding due to sodium and calcium sulphate formation. Prepr. Pap. Am. Chem. Soc. Div. Fuel Chem. 2004, 49, 169-172.

86. Wan, Q.; Duan, L.; Li, J.; Chen, L.; He, K.; Hao, J. Deactivation performance and mechanism of alkali (earth) metals on $\mathrm{V}_{2} \mathrm{O}_{5}-\mathrm{WO}_{3} / \mathrm{TiO}_{2}$ catalyst for oxidation of gaseous elemental mercury in simulated coal-fired flue gas. Catal. Today 2011, 175, 189-195.

87. Guo, X.; Beutler, J.; Anderson, C.; Nackos, A.; Ashton, J.; Bartholomew, C.; Hecker, W.; Baxter, L. Poisoning/Deactivation Study of $\mathrm{V}_{2} \mathrm{O}_{5} / \mathrm{TiO}_{2}$ SCR Catalysts. In Proceedings of ACERC Annual Conference, Provo, UT, USA, 26 February 2008.

88. Staudt, E.J.; Engelmeyer, T.; Weston, H.W.; Sigling, R. The impact of arsenic on coal fired power plants equipped with SCR. Presented at ICAC Forum, Houston, TX, USA, 12-13 February 2002. 
89. Thowarth, H. Trace Element Behavior in Pulverised Fuel Fired Power Plants-Impact of Fuels and Emission Control Technologies; Cuvillier Verlag: Göttingen, Germany, 2007.

90. Senior, C.; Lignell, O.D.; Sarofim, F.A.; Mehta, A. Modelling arsenic partitioning in coal-fired power plants. Combust. Flame 2006, 1473, 209-221.

91. Senior, C. Oxidation of mercury across selective catalytic reduction catalysts in coal fired power plants. J. Air Waste Manag. Assoc. 2006, 56, 23-31.

92. Liu, J.; He, M.; Zheng, C.; Chang, M. Density functional theory study of mercury adsorption on $\mathrm{V}_{2} \mathrm{O}_{5}(001)$ surface with implications for oxidation. Proc. Combust. Inst. 2011, 33, 2771-2777.

93. Madsen, K.; Jensen, D.A.; Frandsen, J.F.; Thogersen, R.J. A mechanistic Study on the Inhibition of the DeNOx Reaction on the Mercury Oxidation over SCR catalysts. In Proceedings of Air Quality VIII Conference, Arlington, VA, USA, 24-27 October 2011.

94. Stolle, R.; Köser, H.; Gutberlet, H. Determination of Hg-oxidation-activity of SCR-DeNOx-catalysts. Presented at VGB Workshop "Flue Gas Cleaning 2008", Vilnius, Lithuania, 3-4 June 2008.

95. Zeng, K.; Stolle, R.; Köser, H. Quecksilberoxidation an metalleoxiddotierten SCR-DeNOx-Katalysatoren. In Proceedings of ProzessNet Conference, Mannheim, Germany, 8-10 September 2009.

96. Kai, K.; Kato, Y.; Kikkawa, H.; Imada, N.; Nagai, Y. New SCR Catalysts with Improved Mercury Oxidation for Bituminous Coal-Fired Boilers. In Proceedings of Air Quality Conference, Arlington, VA, USA, 24-27 September 2007.

97. Kai, K.; Kato, Y. Catalysts for oxidation of metal mercury. WIPO Patent Application WO/2008/035773, 27 March 2008.

98. Nochi, K.; Yonemura, M.; Kiyosawa, M. Mercury oxidation catalyst and method for producing the same. U.S. Patent Application 2011/0082028A1, 7 April 2011.

99. Kai, K.; Kato, Y. Oxidation treatment of metallic mercury in flue gas using oxidation catalysts. JP Patent 2010/088984A, 22 April 2010.

100. Kai, K.; Kato, Y.; Imada, N. Method and catalyst for oxidation treatment of mercury metal in flue gas. JP Patent 2010/088983A, 22 April 2010.

101. Kai, K.; Kato, Y. Method for waste gas treatment with a catalyst. JP Patent 2009226238A, 8 October 2009.

102. Nagayasu, T.; Nakashoji, H.; Imai, N. Multi-pollutant control capabilities of double contact flow scrubber (DCFS). VGB PowerTech 2011, 91, 68-73.

103. Zhuang, Y.; Thompson, S.J.; Zxgarlicke, J.C.; Pavlish, H.J. Impact of calcium chloride addition on mercury transformations and control in coal flue gas. Fuel 2007, 86, 2351-2359.

104. Niksa, S.; Padak, B.; Krishnakumar, B.; Naik, V.C. Process Chemistry of Br addition to utility flue gas for Hg emissions control. Energy Fuels 2010, 24, 1020-1029.

105. Wang, H.; Zhou, S.; Xiao, L.; Wang, Y.; Liu, Y.; Wu, Z. Titania nanotubes-A unique photocatalyst and adsorbent for elemental mercury removal. Catal. Today 2011, 175, 202-208.

106. Snider, G.; Ariya, P. Photo-catalytic oxidation reaction of gaseous mercury over titanium dioxide nanoparticle surfaces. Chem. Phys. Lett. 2010, 491, 23-28.

107. Jeon, H.S.; Eom, Y.; Lee, G.T. Photocatalytic oxidation of gas-phase elemental mercury by nanotitanosilicate fibers. Chemosphere 2008, 71, 969-974. 
108. Guo, Y.; Yan, N.; Yang, S.; Qu, Z.; Wu, Z.; Liu, Y.; Liu, P.; Jia, J. Conversion of elemental mercury with a novel membrane delivery catalytic oxidation system (MDCOs). Environ. Sci. Technol. 2011, 45, 706-711.

109. Granite, J.E.; Freeman, C.M.; Hargis, A.R.; O’Dowd, J.W.; Pennline, H.W. The thief process for mercury removal from flue gas. J. Environ. Manag. 2006, 84, 628-634.

110. Dunham, E.G.; DeWall, A.R.; Senior, L.C. Fixed-bed studies of the interactions between mercury and coal combustion fly ash. Fuel Process. Technol. 2003, 82, 197-213.

111. Claudino, A.; Soares, J.L.; Moreira, M.P.F.R.; José, J.H. Adsorption equilibrium and breakthrough analysis for NO adsorption on activated carbons at low temperatures. Carbon 2004, 42, 1483-1490.

112. Ochiai, R.; Uddin, A.Md.; Sasaoka, E.; Wu, S. Effects of $\mathrm{HCl}$ and $\mathrm{SO}_{2}$ concentration on mercury removal by activated carbon sorbents in coal-derived flue gas. Energy Fuels 2009, 23, $4734-4739$.

113. Presto, A.A.; Granite, E.J. Impact of sulfur oxides on mercury capture by activated carbon. Environ. Sci. Technol. 2007, 41, 6579-6584.

(C) 2012 by the authors; licensee MDPI, Basel, Switzerland. This article is an open access article distributed under the terms and conditions of the Creative Commons Attribution license (http://creativecommons.org/licenses/by/3.0/). 